Portland State University

PDXScholar

\title{
The philosophy of William James as related to Charles Renouvier, Henri Bergson, Maurice Blondel and Emile Boutroux
}

Peggy Lyne Hurtado

Portland State University

Follow this and additional works at: https://pdxscholar.library.pdx.edu/open_access_etds

Part of the Intellectual History Commons, and the Philosophy Commons Let us know how access to this document benefits you.

\section{Recommended Citation}

Hurtado, Peggy Lyne, "The philosophy of William James as related to Charles Renouvier, Henri Bergson, Maurice Blondel and Emile Boutroux" (1987). Dissertations and Theses. Paper 3713.

https://doi.org/10.15760/etd.5597

This Thesis is brought to you for free and open access. It has been accepted for inclusion in Dissertations and Theses by an authorized administrator of PDXScholar. Please contact us if we can make this document more accessible: pdxscholar@pdx.edu. 
AN ABSTRACT OF THE THESIS OF Peggy lyne Hurtado for the Master of Arts in History presented June 10, 1987.

Title: The Philosophy of William James as Related to Charles Renouvier, Henri Bergson, Maurice Blondel and Emile Boutroux.

APPROVED BY MEMBERS OF THE THESIS COMMITTEE:

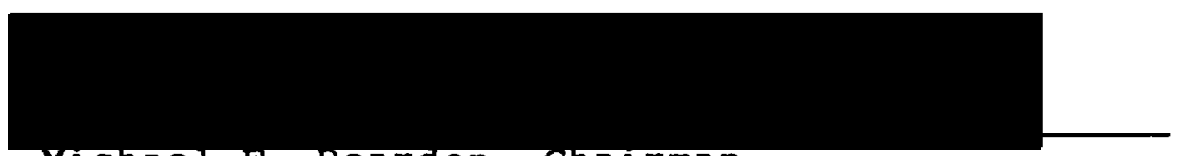

Michael F. Reardon, Chairman

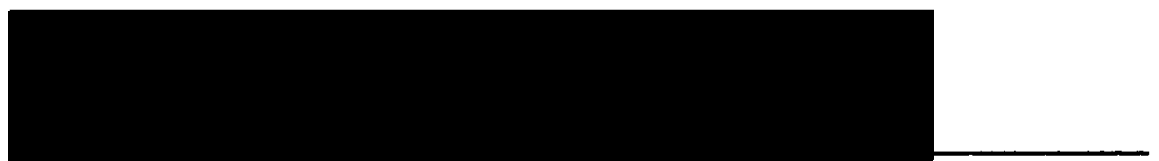

Charlgy Le Guin

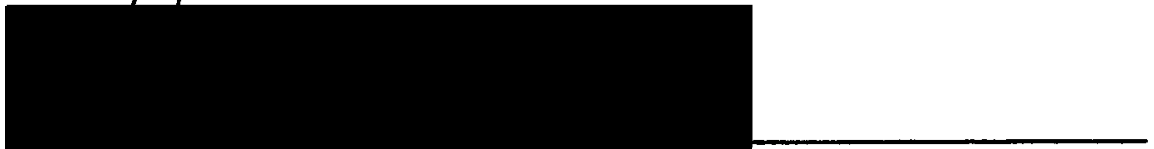

David Johngon

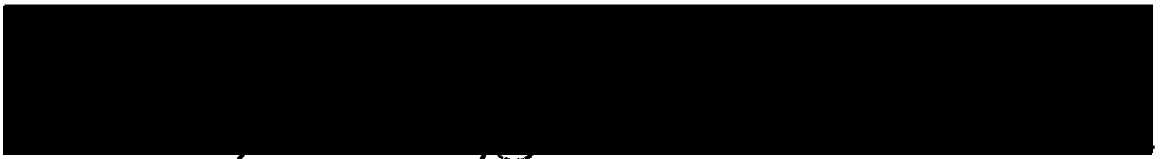

Larry Boplden

This thesis argues two issues: William James' philosophy was to a great extent derived from his interaction with the French philosophers, Charles Renouvier, Henri Bergson, Maurice Blondel and Emile Boutroux. Correlative to the fact that these five figures have an intellectual 
relationship with one another, I also argue that in order to understand James, he must be placed within the context of these relations. These five philosophers, as a group, can be clearly seen and understood in the context of an identifiable movement. Each one was a part of a whole reality with their own slightly different perspectives. However, the context that I present reveals the motivating factors of this movement towards a philosophy of action. This is not to say that there was one defined philosophy of action. Each contributed to the conception of a philosophy of action by their response to the same dilemmas of their time.

The challenge science presented to religious experience created the 19th Century conflict between science and religion. The activities of the Action Francaise, Catholic Modernists and Neo-Thomists illustrate responses that sought to account for the relation between the physical and the metaphysical. The intrusion of scientism into philosophic discourse and the use of philosophy as a political tool threatened intellectual freedom and stimulated the formulation of an alternative conception of philosophy held in common by James and these four French philosophers.

James participated in this movement to invigorate and broaden philosophic inquiry. James rejected the idea of scientific knowledge confined to strictly logical procedures. James and these French philosophers put forward the idea of 
rational inquiry designed to accommodate the irrational in experience. To do so required a new foundation for philosophy, which they found by an analysis of experience that revealed the common component in all human experience to be action, which includes the will and intelligence. From this view, there are no guarantees nor absolute truths. The amount of good existing would be in proportion to the amount of effort expended. The pursuit of knowledge as an activity includes the human will. Knowledge, then, includes a subjective element that places it within political relationships. Because of the nature of human inquiry, a check on unwarranted assertions could be in force by tailoring a method appropriate for each object of investigation that insures the ability to speak in terms of the reality investigated.

It is clear from their correspondence and works that these five philosophers had a symbiotic relationship. The designation "philosophy of action" means that they each developed a philosophical viewpoint that rejected the closed, fixed systems based on a conception of external verification, and adopted a conception of the intrinsic source of knowledge found within the relations of man and his environment that supported an open-ended, pluralistic, idealistic, empirical philosophy. The influence of these French philosophers on James is seen in his adoption of free will, his inclusion of 
the experience of relations in the knowing relationship (which means that truth is a product of contextual verification), and his metaphysical position of Radical Empiricism with its view of a self-reparative world of becoming. James and these French philosophers each articulated a change in mentality seen in the 19 th Century that sought to understand the world from the human perspective. 
THE PHILOSOPHY OF WILLIAM JAMES AS RELATED TO CHARLES RENOUVIER, HENRI BERGSON, MAURICE BLONDEL AND EMILE BOUTROUX

by

PEGGY LYNE HURTADO

A thesis submitted in partial fulfillment of the reguirements for the degree of

\author{
MASTER OF ARTS \\ in \\ HI STORY
}

Portland State University

1987 
TO THE OFFICE OF GRADUATE STUDIES AND RESEARCH:

The members of the Committee approve the thesis of Peggy Lyne Hurtado presented June 10, 1987.

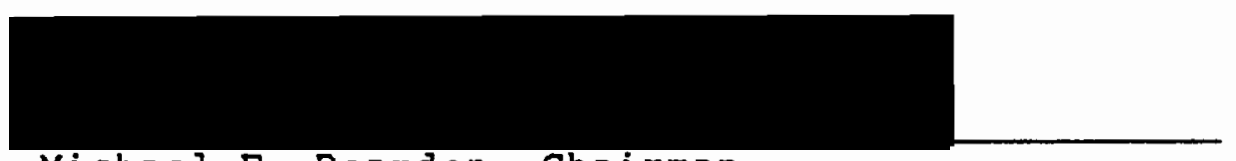

$$
\text { Michael F. Reardon, Chairman }
$$

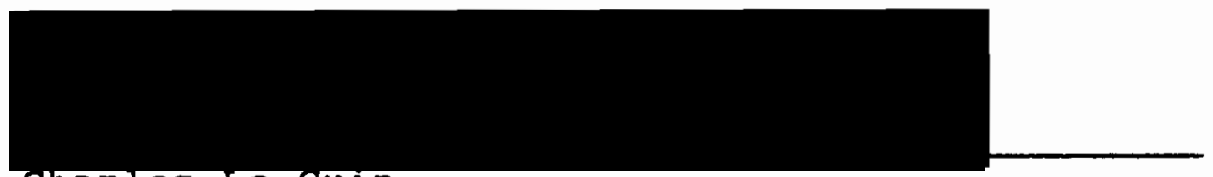

Charles Le Guin

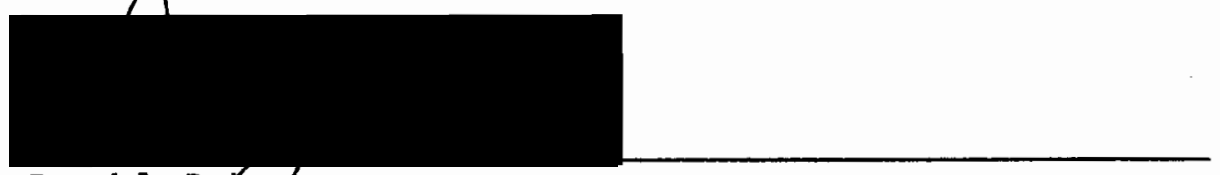

David Johnson

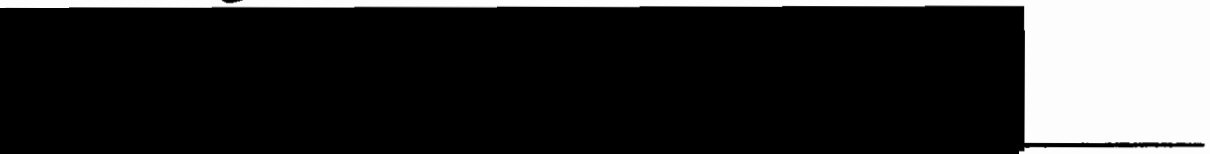

Larry Boylden

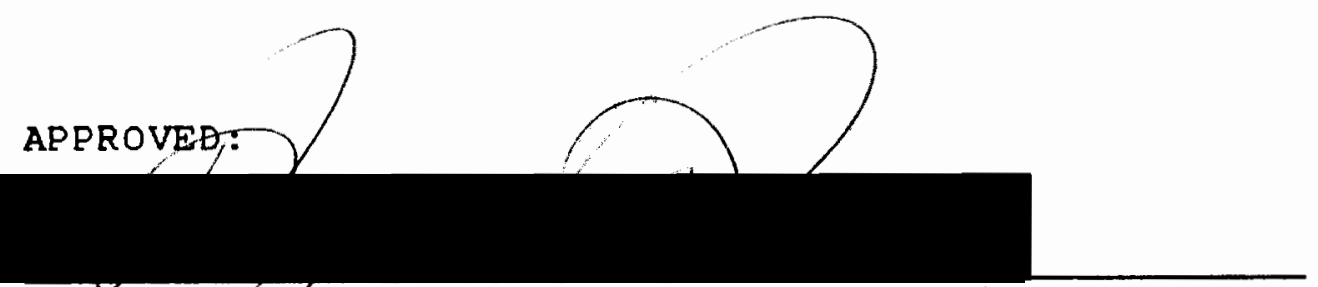

Berhard Burke, Head, Department of History

Bernard Ross, Dean of Graduate Studies and Research 
TABLE OF CONTENTS

PAGE

CHAPTER

I INTRODUCTION . . . . . . . . . . . . . . . 1

I I HISTORICAL CONTEXT . . . . . . . . . . . . 13

The United States. . . . . . . . 13

France . . . . . . . . . . . 25

The Third French Republic. . . . . 27

Positivism and the Third French

Republic.............. 33

Catholicism In France. . . . . . . 39

The Task In Common . . . . . . . . 49

I I WILLIAM JAMES, CHARLES RENOUVIER AND

HENRI BERGSON . . . . . . . . . . . . . . 58

James: His Thought and Philosophical

Problems............. 63

IV WILLIAM JAMES, MAURICE BLONDEL AND EMILE BOUTROUX . . . . . . . . . . . 100

James and Emile Boutroux . . . . . 110

V CONCLUSION . . . . . . . . . . . . . . 127

BIBLIOGRAPHY . . . . . . . . . . . . . . . . . . . . 140 


\section{CHAPTER I}

\section{INTRODUCTION}

This thesis will examine the thought of the American philosopher, William James (1842-1910), and its interrelationship with the French philosophers, Charles Renouvier, Henri Bergson, Maurice Blondel and Emile Boutroux. As intellectual history, my approach is patterned after the method of Albert Levi, Michel Foucault and Edward Said. Their works demonstrate that what is said to be objective knowledge is not impervious to external influences. Their method can be illustrated by drawing from the work of each of these scholars.

Levi posits that we can view philosophy without "pleading a special metaphysical case." ${ }^{1}$ Levi characterizes his book, Philosophy and the Modern World, as a "species of intellectual history." Rather than pursue philosophical criticism to ascertain an independent "truth" of ideas, Levi sets the development of philosophical systems in their relation to the dynamic movement of the particular societies with their contemporary developments. In his overview of the history of philosophical systems, Levi posits that man's formulation of conceptions about himself and life emerge in response to past conceptions, 
and the developments of his own age. These conceptions are developed as programs for inguiry.

Levi holds the thesis that philosophies can be seen as "varieties of contemporary intellectual experience." They paint a cultural portrait of an age precisely because they are a product of the social context that includes the philosopher. There is an "observable correlation between the form of any society" and the ideas that inform personal 2 conceptions .

Levi explains his approach by reference to past philosophical systems. As an example, he points to the intellectual unity of the medieval synthesis as based upon the unity of social structure. The limited number of authoritative texts allowed an intellectual integration that the "modern consciousness" has not been able to achieve in large measure due to the multiplicity of views available to the modern reader. Our modern world is an "open" society in that there is no "consensus of belief guaranteed by a single authoritative intellectual elite;" consequently, "corresponding to the new social pluralism there develops an intellectual pluralism."

An example of the contextual nature of philosophical systems is found in reading Descartes' Meditations. Levi points out that we must consider that a man as old as Descartes, with his education and experience could not, in 
actual fact, strip his mind of everything except doubt. Descartes employed this procedure as a technical device to invite the reader into an "as if" situation in order to argue his case. Further, Levi points out that by looking at the development of science by Descartes' time, we recognize that the development of the mathematical sciences motivated Descartes to construct a philosophy of nature and a "picture of the human person" upon the very mathematical foundations of his historical context.

Michel Foucault investigated the relationship between power and knowledge. Foucault demonstrated how systems of authority emerge from the confluence of disparate circumstances. A cogent example is developed in Madness and Civilization. Foucault analyzes the effect of historical context in shaping the system for handling those labelled as insane. We find that the empty poor houses, the fear of the irrational, the organization of modern society, and the professionalization of the bourgeoisie, all played roles in the development of insane asylums to quarantine the perceived "misfits" of society. The physician was placed in charge primarily due to his respectability, and eventually methods were used on the patients to adjust their thinking to be in line with middle class conceptions of proper conduct and productive work assumed to apply to everyone. There was no advance plan to 
orchestrate this outcome; rather, there were only multiple circumstances and problems to be resolved that came together in the formulation of a particular mentality.

Edward Said, in orientalism, explained the principles of his methodology which are in contradistinction to the non-political nature assumed to exist in the humanities and history. For said, there is no such thing as a "pure, or 7

unconditional" idea. Particular areas of study do not exist only in texts, they are part of a larger whole. Said points out that conceptions about the orient play a cultural role that connects "ideology, politics and the logic of power." Said states that his work is an investigation of authority:

There is nothing mysterious or natural about authority. It is formed, irradiated, disseminated; it is instrumental, it is persuasive; it has status, it establishes canons of taste and value; it is virtually indistinguishable from certain ideas it dignifies as true, and from traditions, perceptions, and judgments it forms, transmits, reproduces. Above all, authority can, indeed must, be analyzed. 8

For Said, scholarship is "willed human work" accomplished within a complex historical setting. Said addresses the question of how we can treat the cultural, historical phenomenon without losing sight of the relation between politics and culture. There is no fixed rule:

My argument is that each humanistic investigation must formulate the nature of that connection in the specific context of the study, the subject matter, and its historical circumstances.9 
One can make a powerful argument for said's belief that all texts are "worldly and circumstantial and vary between genres and historical periods." Additionally, individual writers make an imprint on any "discursive formations." I have applied said's conception of the personal dimension under consideration in this thesis:

The starting-point of critical elaboration is the consciousness of what one really is, and is 'knowing thyself' as a product of the historical process to date, which has deposited in you an infinity of traces, without leaving an inventory. Therefore, it is imperative at the outset to compile such an inventory.10

The essence of the scholarly approaches of Levi, Foucault and said is that there is no such thing as a contextually neutral idea. I have applied this contextual method in my study of the philosophy of William James.

This thesis will argue two issues: William James' philosophy was to a great extent derived from his interaction with the French philosophers, Charles Renouvier, Henri Bergson, Maurice Blondel and Emile Boutroux. Correlative to the fact that these five figures have an intellectual relationship with one another, I will argue that to understand James he must be placed within the context of these relations. These five philosophers, as a group, can be clearly seen and understood in the context of an identifiable movement. Each one was a part of a whole reality with their own slightly different 
perspectives. However, the context that I will describe reveals the motivating factors of this movement towards a philosophy of action. This is not to say that there was one defined philosophy of action. Each contributed to the conception of a philosophy of action by their response to the same dilemmas of their time. They each address part of the total project.

Although the historical context in France and the United states differed, James could identify with these French philosophers because there was an underlying commonality in their situations. In the United states, post-Civil War concern to develop science was manifested in a movement within the universities designed to establish a respectable intellectual place in the international context. This endeavor led to an academic politics centered around the issue of identifying what science was.

In the 19th Century, the word "science" was subject to diverse usage, either science as knowledge in general or science as a reference to a branch of knowledge with specific procedures. Debates ensued to decide the exact nature of scientific method, to define what conception of science should prevail, and to determine what objects of knowledge would be susceptible to scientific authority. The successes of physics convinced many that without the 
scientific stamp of authenticity, a subject could be dismissed derogatorily as "subjective opinion."

Advances in science and technology challenged prevailing philosophies. Since the scientific revolution, various systems were devised to provide a rational explanation of the world. For some, rational thought found its epitomy in mathematical, or formally logical expression. Although an abstraction of only a part of human experience, rationalists felt that confidence in logical certitude was more valuable then the chaos of irrational aspects of human experience.

Logical procedures, then, were to be in force in the pursuit of knowledge. Objective analysis expressed in logical/mathematical terms would insure the objective value of physics and were thought to be applicable in all branches of knowledge that claimed the name of "science." The human sciences tried to develop according to the model of physics. Laboratory experimentation in physiology, biology and psychology was designed to produce objective "data" that placed man's physical and affective life within an explanatory system in mechanistic terms. Practitions of this method were called empiricists, which, says James, is "your lover of facts in all their crude variety." 11

Since the Age of Reason, the belief in God's laws was steadily loosing ground to the logos of natural laws. 
Information supplied by the scientific method left aside man's spiritual life. Religious authority could not easily communicate the miraculous to those schooled in terms of objectivity. If all knowledge was to be objective, then to both rationalist and empiricist, the question of God's relation to man was generalized and abstracted to the point of near meaninglessness in terms such as the "Unknowable."

Those who objected to a view of objectivity defined exclusively by external natural phenomena were labelled "anti-intellectualists," meaning that their vision of the world did not correctly limit itself to that which was confined to rigidly logical terms. Nor did the so-called "anti-intellectualists" believe that external natural phenomena were satisfactorily explained by the rationalist conception of it. They were called subjectivists because they claimed that man was the author of his vision of truth even though he called it "objective." James, Renouvier, Bergson, Blondel and Boutroux were each charged with subjectivism.

To understand these labels, a few definitions need to be put forth as guides in pursuing the philosophic views of these five philosophers. They opposed absolutism, materialism, rationalism and scientism. By "absolutism" they meant the view that there was only one way of looking at things. For absolutists, truth was fixed according to 
necessary, invariable rules. By "materialism" they had in mind the view that these "fixed and invariable" truths were mechanistic; truth was the unfolding of mechanical laws in physical nature. "Rationalism" referred to the view that sensation, or physical experience, was inferior to the higher truth of the mind. "scientism" basically meant positivism or the idea that all supra-physical explanations, or beliefs, were unverifiable and, consequently, were outside of the knowing relationship. Religious and metaphysical questions about man's relations beyond the physical were meaningless in the view of scientism.

James held that "No one can 1 ive an hour without both facts and principles, so it is a difference rather of emphasis," rationalist or empiricist, the contrast was "simple and massive." Recognizing that philosophies changed according to historical circumstances, James and these French philosophers sought to develop a vision of the world that was harmonious with their cultural experience. Nineteenth century positivism applied one method to all fields of inquiry, which imposed an either/or choice between facts and principles, between science and religion. For James and these French philosophers, the issue could be avoided if the question was posed in terms of the relation between method and object. James derived his pragmatic 
method and his metaphysics, that he called Radical Empiricism, from French philosophy and its synthesis of Kant and comte. In particular, we will see that Renouvier's idealistic, empiristic, phenomenological conception of free will were the essential seeds of James' philosophy which offered the alternative view of an open attitude:

Ought not the existence of the various types of thinking which we have reviewed, each so splendid for certain purposes, yet all conflicting still, and neither one of them able to support a claim of absolute veracity, to awaken a presumption favorable to the pragmatistic view that all our theories are instrumental, are mental modes of adaptation to reality. Certainly the restlessness of the actual theoretic situation, the value for some purposes of each thought-level, and the inability of either to expel the others decisively, suggest this pragmatistic view. 12

By "modes of adaption," James meant to reject the intellectual battles within the universities and stress the fact that there was a level where both science and religion were manifestations of action.

The same situation occurred in France on a larger scale. Republican politics had embraced the exclusive reliance on objectivity characteristic of positivism as its ideological base, thereby, drawing philosophy into political battles. Focusing on politics and culture, I propose to begin with the historical context in the United states and France. I have consciously included a disproportionate amount of French history because the 
political battles there were as large as life itself. The French situation was not only complex by its diversity but it magnified the important issues that directly effected these philosophers and must be understood if we are to understand James' philosophy and his participation in the movement for a philosophy of action. For James, Renouvier, Bergson, Blondel and Boutroux, the divisions in their culture manifested a pluralism in politics and thought. They each sought an acceptable philosophical position that allowed intellectual freedom in the face of such pluralism. 
Notes

1

Albert William Levi, Philosophy and the Modern

World (Bloomington: Indiana University press, 1970) viii.

2

Levi 11.

3

Levi $6,29$.

4

Levi ix.

5

Levi 33 .

6

Michel Foucault, Madness and Civilization: A

History of Insanity in the Age of Reason (New York:

Random House, Inc., 1965) 179, 214-20, 237, 257, 289.

7

Edward W. Said, Orientalism (New York: Vintage Books, 1979) 23.

8

Said $19,24$.

9

Said 15 .

10

Said 25 .

11

William James, Pragmatism ed. Bruce Kuklick (1907 Cambridge: Hackett Publishing Company, 1982) 9.

12

James, Pragmatism 87. 


\section{CHAPTER I I}

HISTORICAL CONTEXT

THE UNITED STATES

In the first half of the 19th Century, the United States experienced a profound growth of industrialization. Industrialization was most pronounced in the Northern states. In contrast, the economic base of the southern states remained essentially agricultural. Their agrarian culture was dependent on black slave labor in the production of crops, such as cotton and tobacco, at a cost that could compete in foreign markets. The supply of cotton for England's industrial mills was critical to the Southern economy.

Thoughout the 1850's dissension between the Northern and southern states increased to critical proportions. The discord revolved around two main issues: 1) The abolition of slavery and the guarantee of individual rights, and 2) the Federal governments authority to enact laws applicable to all of the states. The Presidential election of the Republican, Abraham Lincoln, in 1860, was followed by the Southern succession from the Union and the formation of a Southern Confederacy. As a result, Civil War ensued from 
1861-1865, which ended in victory for the North and the federal union of all of the states.

The post-Civil War reconstruction included the national political need to provide a common focus for America in order to raise political consciousness above the level of regional divisions. Along with the domestic political and economic needs of the United States, there was the desire to overcome the "colonial mentality" attributed to the United States, and establish the United states as an intellectual and political power of importance 1

within the larger international context. The development of science, as a means to promote American interests was an important part of the overall political agenda.

To involve America in scientific questions, Congress authorized four surveys of the American West. Federally financed research promoted a competition for the funding of 2

scientific research. Harvard, Princeton and other institutions of higher education were involved in a process of organizing education in accordance with the national demands for the wedding of science, technology and professionalism. There were political ramifications within institutions of higher education as each strove to establish themselves as preeminent academic institutions within the international community. 
The second half of the 19th Century saw the organization of graduate schools and a competition to attract and produce internationally recognized scholars. As an example Louis Agassiz, a renowned Swiss scientist, won Americans' hearts because he choose to remain at Harvard in order to study natural phenomena in America. He organized the Museum of Comparative Zoology at Harvard to "be one of the great scientific institutions of the world." Agassiz' project of writing a natural history using American specimens brought donations of both funding and specimens from the American public.

The scientific needs of the United States legitimized the placement of scientific investigations as a primary goal. The problems for the pursuit of overall knowledge was the incomplete understanding of the nature of scientific investigation. Its scope and limitations concerned intellectuals like James who believed in the efficacy of the scientific method but found its intrusion into the humanities caused a myopic vision that threatened the exercise of intellectual freedom.

The debates over Darwin exemplify the problems that occurred when facts about the physical nature of the world and man obtained by scientific observation were employed in theoretical explanations of the affective, spiritual and moral 1 ife of man. The prestige of men of science had grown 
to such an extent that they were publicly speculating on areas of life outside their expertise. They generalized information that obtained in mechanistic operations and applied it to ultimate questions. The generalization of mechanistic operations in addressing ultimate questions obscured the hypothetical nature of inquiry and encouraged assertions about personal concerns that minimized the importance of the individual.

In the academic world, Darwinism's impact was immense. Debates about conclusions and interpretations of Charles Darwin's (1809-1882) work varied and often reflected the application of arbitrarily selected portions of Darwin's thought applied to contemporary concerns rather than a fidelity to Darwin. Thus, references to Darwin should be read as references to the variety of forms found under the general heading of Darwinism. Darwin's theory of natural selection was not, at first, as much of a problem as was establishing the fact of evolution at all.

At first, Darwinism had to compete with NeoLamarckianism, which was an alternative explanation of evolution. At the turn-of-the-century, there were more Neo-Lamarckians than Darwinists in the United states. NeoLamarckian evolutionary thought stressed a process of growth and decline, of "discernible patterns of youth, maturity and senescence"; when vitality was depleted, 
8

extinction occurred. Neo-Lamarckian transformism accommodated acknowledgment of an original force that set the world and life going and supplied it with the mechanism that kept it going. Science and some conception of a creator could co-exist and even relate as parts of a whole. In 1868, James McCosh, the new President of Princeton, "openly avowed his belief that evolution and Christianity could coexist."

A close relationship existed between science and 10

religion in the United states. Considering the relatively sceptical reception of Darwin's earlier works, religious leaders thought that scientists would respond negatively to Darwin's origin of Species (1859). However, Origin of species was taken seriously. As early as 1866, Jeffries Wyman had supported Darwin when Wyman showed that there was an "irregularity in bee cell construction that was visible to the naked eye--so instinct was not invariable." $^{11}$ The challenge for Darwinism was the issue of genetics. Random selection in a process of continuous growth contradicted the pattern of growth and decline by which Neo-Lamarckianism explained evolution. Finally, the recognition of Mendelian genetics meant Neo-Lamarckianism's decline and an increased preference for Darwinism. 12

Scientists and theologians came to accept the coexistence of some causal form and evolution, yet the theory 
of natural selection, with chance as the formative principle of species, was a matter for continued debate. Interpretations of the theory of natural selection were put forth that explained original design in terms of the laws 13 of nature.

In an age of physics, primary qualities and evidence of materiality were most important. With Darwin and Wund, "It is the sciences of $l$ ife and of consciousness which occupy men's minds and in which they might rightfully seek the clue to an adequate metaphysics." 14 To pattern the nonphysical on a physical model accentuated the differences of the objects by the limited explanation afforded by physical terms. The problem for the individual was that the life they lived and experienced did not run like a machine. Moral philosophy was required as individual decisions had to be made on every conceivable issue as a member of a democratic society. It was left to individual citizens to decide what was equally good or bad for both society and themselves.

Darwin's particular blend of science and speculative theory created an acute challenge to the already precarious footing of religious experience. Darwin's theory of natural selection seemed to many to be so mechanistic as to relegate spiritual experience as unimportant and ineffective. In a sweep the idea of an absolute external 
authority was replaced by law built into man's own person. As Levi put it:

The body with its quaint apparatus of perception and motor habit becomes now not a cradle of man's reason, nor the fretful bearer of his immortality, but simply an instrument of action, and of action only.15

Although emotional experiences were a part of man's 1 ife, they were the least possible to understand because they functioned outside the law as irrational experiences. As Levi put it, Darwinism carried two themes seemingly at odds: 1) Man's life depended on mechanism, susceptible of analysis. 2) Man's physical continuity with the animal world was reflected in his irrationality. The central place of irrationality brought into question the "insights of a philosophical tradition which dominated Western thought for 2,000 years." 16

Evolution prevailed as far as its acceptance meant the recognition that man evolved from the lower animals, and that man could look at himself from an earthly perspective, rather than from a conception of God as an external creator. Man could look at himself as a source of knowledge and work his way outward. Darwinism potentially reversed the traditional point of view. If carried to a theoretical level, evolutionary conceptions confined to mechanism, meant man was not free at all; man had no "freewill" or power to direct his life. Without the ability to 
wield a power effective over human life, man would be unable to govern himself. Accepting a positive method to ensure that what was known was true, even if it was necessary to limit what could be known, was one reaction to the dilemma. As such, positivism was fine as far as it went. The problem was that it did not go far enough.

William James' philosophy was intimately involved with the questions Darwinism raised. Although James was a proponent of Darwin and science, he objected to authorities who rigidly promoted their interpretations of these viewpoints in every field. In his 1879 essay on "The Sentiment of Rationality," James took the position that his entire philosophical effort maintained:

Materialism will always fail of universal adoption. For materialism denies reality to the objects of almost all the impulses which we most cherish. Any philosophy which annihilates the validity of the reference by explaining away its objects or translating them into terms of no emotional pertinency, leaves the mind with little to care or act for. In short, we go in against materialism very much as we should go in, had we a chance, against the second French empire...or any other system of things toward which our repugnance is vast enough to determine energetic action, but too vague to issue in distinct argumentation.17

Although opposed to materialism, James did not abandon practical reality for abstract religious doctrines. He specifically singled out the negative influence of rigid religious dogmas setting the questions for knowledge in 18 general. For James, there was a difference between 
religious institutions and religious experience. James proposed to begin with the individual religious experience in order to ascertain what parts of man's personal experiences were shared in common with humanity. 19 His concern with religion, science and philosophy was to approach each subject in terms of the object appropriate to it. The rejection of the spiritual for the physical, or the physical for the spiritual was unacceptable. scientific investigation required clarification but its application to religious, or metaphysical questions prompted James to concentrate on the latter to ascertain the relation between science and religion. He pursued an integral approach to knowledge in that his object was the whole of human experience. Oliver Wendell Holmes, a lifelong friend of James', said after reading Pragmatism: "I now see, as I have seen in his other books that I have read, that the aim and end of the whole business is religious."

In an 1876 article in The Nation James called attention to the problems that were to preoccupy $h$ is generation: 1) The form of philosophic problems and discussions should not be set by the Church. 2) All questions should proceed as if there was no official answer "preoccupying the field." 3) Philosophy "means the habit of al ways seeing an alternative...of making 
conventionalities fluid again...it means the possession of mental perspective." 4) scientific advances required "a change in the method and personnel of philosophic study." The philosopher had to be able to understand and account for a vast amount of new facts with metaphysical implications, such as Darwinism.

James had begun his academic career just before institutional politics in higher education began to intensify. His professional career was marked by the political tensions within Harvard and between Harvard and other institutions. The desire to become a world-class institution and attract and produce renowned scholars had deleterious consequences for those who did not fit in, such as Charles S. Pierce. James' friendship with Pierce began in $h$ is college years when they were fellow members of the small group of men that formed "The Metaphysical club" in 22

the early 1870's. James and his father worked on behalf of obtaining an appointment for Pierce in a university. However, Pierce's ill-humour and independence of thought worked against a permanent appointment.

It was from Pierce that James had borrowed the term pragmatism. However, regardless of Pierce's genius, James' efforts to get Charles Eliot, the President of Harvard, to give Pierce an appointment were regularly refused. 
The changes in higher education from the 1890's onwards, brought responses from James. In 1892 James' essay "A plea for Psychology as a Natural Science" expressed his dismay over the conditions of psychology, which were "as a mass of phenomenal description, gossip and 25

myth." For James, psychology should renounce ultimate questions and be organized as a natural science. As such, psychology would leave the ultimate questions to philosophy and develop according to its object. Psychology was to seek practical rules for educators, doctors, clergyman and "asylum-superintendents." separating psychology from philosophy would allow men of facts and laboratories to pursue their questions without the intrusion of metaphysical questions.

The direction of higher education was again addressed by James in his 1903 essay "The Ph.D. Octopus." James lamented the emphasis on higher diplomas over individual "brilliancy and originality." The creation of an atmosphere of supply and demand based on credentials was a part of the general movement for "distinction" in acquiring a reputation. For James, it was a "grotesque tendency" and a "Mandarin disease." The institutionalization of need and motive tended to the development of a "tyrannical Machine." Its fostering transferred the value of talent to an 28

"outward badge."

By so doing, university faculties were 
creating a new class of social failures. The trend for credentials, once begun, threatened that America would become subject to the diminishment of individual spontaneity that plagued European countries, in James' opinion, who by their state examinations and control were a tyranny over intellectual pursuit. For James, the social and political implications were a threat to American freedom.

Another indication of the problem of university prestige can be seen in James' efforts to resign from Harvard. Heart disease was an increasing problem for James. His heart problems motivated a concern to avoid the stresses of course lectures, students and public lectures. In 1900 James offered his resignation to the Harvard Trustees. President Eliot convinced him to postpone it. Repeated attempts to resign were also rejected. In 1904, James again sought to resign and accept a one year appointment at Leland Stanford University. Eliot responded by offering temporary breaks, "but nothing which can in the public eye detach you from the University." Eliot stressed that it would be disadvantageous to Harvard to have James connected with another institution. Eliot appealed to James on the grounds that his continuous connection with the university was an advantage that James owed to Harvard. 
It was not until 1907 that James' resignation was finally 29 accepted.

The problems of education, science, religion and philosophy were all problems that concerned James and the four French philosophers of action next to be considered. In order to understand these philosophers of action, one must have a clear picture of the historical context which prompted the development of their philosophies. In turn, some similarity between conditions in the United states and France account for the sympathy and mutual understanding between James and these French philosophers of action.

\section{France}

In France, national political conflicts affected religious and educational institutions as both were by law state institutions controlled by government officials. The Catholic Church had provided the ideological basis for monarchical government with its belief in the divine rights of kings and was entrenched in social institutions. Although the 1789 revolution brought an end to absolute monarchy, Napoleon's reign reestablished a traditional authoritarian mentality by the institution of centrally controlled state power.

The University of France, established in 1806, gave the state a monopoly over public education. However, from the 1815 restoration onwards the state control of education 
meant that schools, faculties and curriculum were subject to the political changes that occurred throughout the 19 th Century. For example, the failure of the 1848 revolutions triggered a conservative reaction in government and, consequently, in education.

To curb republican sentiment, the state promoted Catholic interests. Soltau designated the period from 1849 to about 1859 as "the Clerico-Bonaparte" alliance, which included: 1) State guarantee of the Church's legal rights and Catholicism as "the religion of the state," 2) the authority of religious orders, 3) censorship of the Press to outlaw criticism of dogma and authority, and 4) a disproportionate influence by Bishops over state agencies regulating University and secondary education. Soltau cited:

In the first four year of Imperial rule the number of state secondary establishments had diminished by 48, that of scholars by 2000, whereas, that of "Eree" (i.e. Church) schools had $r$ isen by 167 and of their scholars by over $10,000 . " 30$

Throughout the $1860 \mathrm{~s}$ protests against the neglect of science and technology increased and culminated in the republican cry, which "hailed the debacle of the "metaphysical" Second Empire and the emergence of the "positivist" Third Republic." ${ }^{31}$ The post-war Republican government unleashed the unresolved questions of the French revolutions. During the second Empire, the Liberal Party 
had been preoccupied with opposing excess rather than with mastering the intricacies of a democratic form of government. Intellectual and religious freedom remained undefined. The shout of a triumphant "positivist" Third Republic in 1870 was premature in the face of a monarchist political majority. To understand the political instability of the Third French Republic, an overview of the interplay between republicans and the monarchists in the national legislative bodies.

The Third French Republic

The Second French Empire entered the Franco-Prussian War (1870) as the strongest military power on the Continent. French pride and confidence in their military capabilities was soon dispelled by the alarming rate of Prussian military successes during the war. The spector of military defeat caused political repercussions in France that culminated in the demise of the second Empire and the establishment of a Government for National Defense choosen by elections to a National Assembly. 33 A Republic was thereby tentatively put into place. Between 1871 and 1879, the outcome of the political contest between monarchists and republicans was the establishment of the Third French Republic (1870-1915). However, for the rest of the century the ramifications of the disparate political conceptions 
held by monarchists and republicans exacerbated the difficulties of republican reconstruction.

During the administration of Aldoph Thiers, from February 1871 to May 1873, the majority of the National Assembly were monarchists who agreed to a Republic and to the National Assembly only as a temporary measure. Desire to both end the war and to place the blame for the war on the republicans were the main reasons for the monarchists' 34

support of the Republic. The monarchists needed time to resolve the problem of authority within their own ranks, which entailed the fusion of the two branches of the House of Bourbon (the Legitimists and the orleanists) in order to accomplish a restoration of a monarchist political 35 agenda.

Toward this end, the monarchist majority succeeded in gaining the readmittance of the princes of the orleánist branch to France and in getting their privileges 36 restored.

Within the ranks of royalists there was fierce disagreement over the choice between a restoration of an absolute monarchy or the establishment of a constitutional monarchy. The members of the younger, Constitutionalist orlean's line, led by the comte de Paris, recognized that once a form of representative government had been institutionalized, the extent of freedom and authority would be perpetually debated. With a strong leader, 
constitutional monarchists hoped to minimize individual freedom by maximizing state authority.

To overcome the divisions between the two branches, the Constitutionalists agreed to accept the leadership of the representative of the Legitimist branch, the comte de 37

Chambord.

The comte de Chambord refused to lead the reconciliation of the two monarchist groups under the Tricolors of the revolutionary flag, which the Constitutionalists required. His archaic ideas were left untouched by his 40 years away from France. Chambord was an extreme absolutist unable to conceive of the legitimacy of any representative government. He remained a believer in the divine right of kings and could not forgive the younger 38

branch for forsaking Louis XVI.

While the monarchists' schism made it impossible for them to consolidate their power, bye-elections were increasing republican membership 39 in the Assembly.

The events of the Mac-Mahon administration, from May, 1873 to January, 1879, show the uncertainties of outcome when questions are decided by representative debate, and his administration shows the precariousness of political alliances. Mac-Mahon's L'ordre moral implied resistence to radicalism (republicanism) and a conservative policy strongly in favor of the Church, yet Mac-Mahon had to work within the Republican system. Although Mac-Mahon was anti- 
republican, the political climate worked against him and his term of office saw the reestablishment of a Republic 40 coupled with a sort of religious revival.

The conservatives had supported Mac-Mahon in opposition to candidates who supported further republican reforms. However, the internal dissension of the conservatives prevented them from developing a unified political program consonant with the requirements encumbent upon Mac-Mahon working within a Republican system. As a result, Mac-Mahon had to rely on coalition ministries difficult to reconcile. Needing time to resolve their difficulties, monarchists moved in opposition to the republicans by carrying a vote giving executive power to Mac-Mahon for a definite period of seven years. By this maneuver, a conservative head of the nation, Mac-Mahon, was provided who it was hoped might outlast the Assembly and act to restore monarchist principles.

\section{1}

Both extreme royalists and extreme radicals Erightened the broad center, which proceeded to chose a conservative republic over either extreme. In January, 1875, an amendment passing by one vote, provided that a President of the Republic be elected by an absolute majority of votes by the senate and the chamber of Deputies, united as a National Assembly. The President would be elected for a seven year term and eligible for 
reelection. This insured that a President would be elected after Mac-Mahon and the transmission of power would occur 42 in a republic.

Thus, the conservative monarchist majority, unable to develop a satisfactory program of their own, was instrumental in establishing the Third French Republic. The political course of events between 1871 and 1879 resulted in the establishment of a president over any French government, the enactment of a constitution, parliament and republic over France, and the election of a republican majority in the Chamber of Deputies and the Senate. However, the political power of the monarchists remained strong and was used to challenge republican reforms whenever possible. The degree of political instability in both the conservative and republican camps of the Third French Republic was reflected in the cabinet dissolutions. In the 41 years of the Third French Republic, 49 cabinets 44 were instituted.

The political tensions that plagued the Third French Republic were dramatized in the case of Alfred Dreyfus. From 1894 to 1906 the sides were drawn between republican and monarchists, and within these two groups, by one's 45 position regarding Alfred Dreyfus. Dreyfus, a Jewish military officer, was wrongly accused and sentenced for treason. For authoritarians, the issue was the public 
admittance that the highest army officials could have made a mistake in accusing Dreyfus. The conservative monarchist's and clergy's platform of traditional law and order endorsed the military as a major force for stability; as such, they considered that the military should not be challenged on peripheral issues. Traditionalists, both republicans on the extreme right and monarchists, advised sacrificing Dreyfus for the higher duty of honoring authority; individual free rights were to be subordinated to order. The twelve years of turmoil over Dreyfus can be seen as a symptom of the difficulty for absolutist convictions to accommodate freedom in politics, religion or education.

Both conservatives and republicans realized that the knowledge transmitted in the educational system could have a strong influence on society in its endorsement of republican or monarchist principles. Conservatives when in political power were in a position to effect social change. Working together, the conservatives made provisions for the expansion of the "free" universities, not under the control of the potentially radical state. In the name of intellectual freedom, Catholic faculties expanded. The instablity of the socio-political situation placed Church, state and education in a state of tension. Expansion of Catholic educational facilities followed by contraction 
and/or persecution paralleled shifts in sentiment toward conservatism and Catholicism. on the other hand, republicans adopted "positive science" as their ideological base and promoted its predominance in the educational system. The consequences of the republican adoption of positivism as their ideological base, can be best understood by looking at the development of Auguste comte's thought and the effect of its application in religious and educational affairs.

\section{Positivism and The Third French Republic}

Auguste Comte's (1798-1857) positive philosophy developed from 1830 onwards. Comte's historical vision of the world in his law of three stages, showed man to have passed through a theological stage, followed by a metaphysical stage that was at the time passing into a positive stage of knowledge whereby the first two stages were superceded by the realization that only positive facts and observable phenomena and the objective relations of these and the laws that determine them were legitimate objects of knowledge. As for religion, abandoning all inquiry into causes or ultimate origins meant that the object of worship would no longer be God, a supernatural external authority; instead of God, the object of worship would be the observable projection of human life in the collective form of Humanity. 
In Politique positive, Book IV, Comte stated his mission:

No more empiricism, no more a priori reasoning. In political philosophy there can be no order or agreement save by fastening social phenomena, just as all other phenomena, down to unchanging natural laws, the sum-total of which traces for every epoch, free from any possible uncertainty, the essential limits and nature of political action. 48

John stuart Mill defined the positivism of Comte as the "substitution of the scientific for the religious point of view, and the application of the philosophical method to social studies."

Comte had designed his systematic organization to work as a whole. Positivists were to devote themselves religiously to Humanity by a "political and moral reconstruction of a society adrift since the French Revolution had brought the old order to its deserved 49

end." The "Positivist society" in Paris was founded in 1848 as a political discussion group with comte as President, with Comte as the High Priest of the "Religion of Humanity" and a committee of three as the temporal power. Comte intended an administration of positivism in 50

France. Comte's early death left his disciples without an appointed successor as High Priest. The followers of Comte were not consistent in their adoption of positivism's tenents. Political programs by both monarchist and republican incorporated only those parts of Comte's thought 
that were consistent with their programs. As the ideological base of the Third Republic, republicans stressed Comte's attack on metaphysical politics. Traditionalists promoted the Comtian argument against revolutionary ideology, excessive focus on individual rights, and especially, his view of the Church as the foundation of social order against revolutionary ideals.

Efforts for positive human sciences were continued by those who interpreted Comte as stressing method.

For Comtism, the real unit of society was the social group, which was defined as a collective embodiment of the past, present and future of Humanity. John stuart Mill described Comtism as "the most complete system of spiritual and temporal despotism that ever issued from the brain of any human being, except perhaps Ignatius Loyola."

Soltau maintained that comte was a political conservative seeking to supply an authority for an aristocratic intelligentsia who would save society from anarchical conceptions of individual freedom. The idea of human right was to be replaced by the discernment of "the true meaning of social evolution" by those trained to examine the facts of tradition, formulate their laws and 53 govern society accordingly.

A philosophy that placed the welfare of the collective above the individual and advocated a republic 
with an elite that appealed to sociology was attractive to the republican bourgeousie who valued order (in their favor) as highly as monarchists. Soltau summarized Comtism's principles as, 1) the belief in a conscious organization of society along scientific lines, 2$)$ the belief in the need for and the possibility of social reconstruction, 3) the recognition of economic factors and the attempt at scientific analysis of existing conditions. Although these convictions were not in themselves untenable, the problem with comtism was that it was presented in "a messianic atmosphere that could only spell ultimate collapse." 54

Early in the Republic the endorsement of republican positivism showed its inadequacies in reconciling the strong partisan passions of the major social groups. Generally, republican positivism held that the catholic Church was inconsistent with positive science and should be stripped of secular power. Republicans emphasized the pernicious historical ties between Catholicism and monarchy. They felt a Republic must educate citizens as republicans, and to put their faith in science rather than religious ideology. Toward this end, the superstitious influence of Catholicism was to be removed from educational institutions. The result was resurgent outbreaks of anticlericalism during the Third Republic. Purging the public 
educational system of religious influence was a complex and massive task in light of the history of the Catholic Church in France. It was so entrenched in the educational system that efforts to separate Church and state magnified the issue between absolutism and freedom.

In 1878 and 1880 scholars suspected of clerical sympathies were removed from prominent academic position. As an example, in 1880 the Catholic philosopher Leon olleLaprune, one of the two major influences on Maurice Blondel, was removed from his academic post. An appeal on his behalf resulted in his reinstatement with the penalty 55 of the lose of one year's salary. The "scientific myth" of the Third Republic was that "science had replaced religion in explaining the world." Exact knowledge was called for by the right of citizens to be taught certain facts deriving from the "pure experimental method."

The conception of a "pure experimental method" that could be applied in all fields provoked responses from a number of influential scientists. Clarification of the relationship between theory and practice put forth by some scientists challenged the conceptions of "old positivism." For example, the conception that one method was applicable to all fields of inguiry was criticized by the French physicist Pierre Duhem (1861-1916). The nature of 
objectivity in the mathematical formulas was expressed in the perspective of Duhem:

Metaphysical and religious doctrines are judgments touching on objective reality, whereas the principles of physical theory are propositions relative to certain mathematical signs stripped of all objective existence. Since they do not have any common terms these two sorts of judgments can neither contradict nor agree with each other.57

Duhem's assertions brought responses from republican officials throughout his professional career. The course of Duhem's career reveals the tyranny that could develop when the ideology of positivism was used to judge the competency of a scholar. It was generally agreed that Duhem's work in theoretical physics was brilliant and that he was a prime candidate for a major post in Paris, the center of the higher education system. Instead, Duhem was given an appointment at Bordeaux in 1895; in 1898 it was noted that his "independence of character was a little excessive." In the middle of the great anti-clerical movement fueled by the controversial Dreyfus Affair, the official report on Duhem's performance stressed the fact that he was an "intransigent Catholic."

The objections to Duhem over a thirty-year period, moved from noting his outspoken, obstinate attitude in theoretical debates with colleagues to branding his behavior with the epithet of "intransigent Catholic." The records show that the republican officials could not 
easily overlook the fact that he was a Catholic. As Paul noted, Duhem's personality may have kept him from an appointment in paris, yet the rectors' reports through the years note his Catholicism as the troublesome point. By 1910 the separation of Church and state had been enacted, which eased the pressure somewhat that had been brought to bear on scholars who happened also to be Catholics. Only then, after 30 years of service, Duhem was no longer seen as a threat. After his death, the street where he had lived in Bordeaux was renamed after him in recognition of his intellectual contributions.

Concern about the relationship between science, religion, and philosophy can be seen in the efforts to formulate a reasonable explanation by those concerned to rescue a position for catholic thought. The difficulties involved were evident in the construction of views that proposed different solutions to the question of the relationship of Christianity in society. Catholicism was the predominant form of Christian thought in France. Therefore, we can look at the thought of Catholic thinkers in order to clarify the issues as seen in the 19th Century.

\section{Catholicism In France}

It must be understood that the Catholic Church in France did not have a monolithic concept of its place in society. The socio-political situation caused the Church 
leaders and concerned Catholics to review their relation to the state and their role in society, to determine what their primary duty was, i.e. spiritual and/or social. Within the Catholic Church itself, the same sides were drawn and the battle took place as it did in parliament and in academic circles. The ideas of the various Catholic Eactions can be seen in the activities of the Action Française, the Catholic Modernists and the Neo-Thomists as each faced the same configuration of questions encountered in the political and academic fields.

As the ideological leader of the Action Francaise from 1899, Charles Maurras opposed romanticism and the ideas of 1789. Individualism, with its egocentric self,

was for Maurras, a social ill requiring exorcism. 59 By 59 synthesizing nationalism, positivism and Catholicism, Mauras wed traditional French politics and religion with a view of science that accommodated absolutism.

Maurras' thought was structured on a brand of nationalism that called positivists and Catholics to join in support of their "common interest." As sutton points out, Maurras had a problem common to many: He was brought up a Catholic; yet, in a world fascinated by science, he was unable to conceive of the world in "theological terms and was distressed at the resultant disorder affecting $h$ is thought and action." 60 
Maurras expressed appreciation for Comte's aphorism 'submission is the basis of perfection.' According to Maurras, Comte affirmed the following: 1) A clear statement of the illogical nature of modern individualism. 2) Men were bound together by race and the law of continuity, which required a state religion to insure continuity of traditional values and order. 3) The Catholic Church was an agent of social order.

Maurras' nationalism resided in the continuous social fact of the nation as the important fact. As Maurras put it, "la patrie" was "the holiest of things," and it was the individual man's responsibility to see to it that the abstract collective of the French nation was paramount over the individual. Since he equated personal identity with one's "Frenchness," it followed that power would then reside in the hands of those authorized to define "Frenchness."

\section{2}

These authorities would be an aristocratic elite, the intelligentia who research and profess within a traditional mentality. For Maurras, the anti-social nature of anarchism, liberalism and individualismall derived from the Protestant Reformation and the assertion of freedom of 63 conscience. Positivism as a description could be used, not as an explanation which required causal connections, but simply as repeating what was seen, fixing the past as 
much as possible into the potentially fluid aspects of experience.

Maurras' Catholicism was said to be Catholicism without religion:

The merit and the honour of Catholicism have been to structure the idea of God and to take away Erom it this poison (of Deism). On the road that leads to God, the Catholic finds legions of intermediaries: some are terrestrial and some supernatural, but the chain from one to another is a continuous one. Heaven and earth are thus amply peopled as once they were with gods. Catholicism proposes the only idea of God that is tolerable in a well organized state. 64

For Maurras, the form of religion without the content should be put to the socially useful task of keeping order within the masses whom he believed were incapable of governing themselves. Man's intelligence was to be used for enlightenment in service to one's country. Maurras made man, in the collective, the center and measure of all 65

things. It was one solution to the problem of the relationship between science and religion.

The French Jesuit, Pedro Descogs published a series of articles in the Jesuit review, Etudes, in which he found a "significant degree of compatibility between many of Mauras' ideas and Catholic doctrine." ${ }^{66}$ The authoritative effect of Jesuit endorsement brought a reaction by Catholic Modernists who objected to Maurras' incorporation of Catholicism into an atheistic conception. 
We can look at the positions of the Catholic NeoThomists and the Catholic Modernists for alternative views on the relation between science and religion. Generally, the advocates of Neo-Thomism were monarchists (authoritarian) and those of Catholic Modernists were more republican in sentiment, reflecting the same divisions within the church as found in secular institutions.

Efforts to harmonize catholic teaching with contemporary thought were launched in the 1879 encyclical by Leo XIII Aeternae Patris, which did not impose Thomism but nevertheless described it "as the most suitable among the philosophies for a victorious defence of religion," and instructed that it should be revived. The 1893 encyclical by Leo XIII, Providentissimus Deus, denied the possiblity of disagreement between theologians and scientists "provided each kept to the proper limits, and affirmed the inerrancy of the Bible in all its parts."

In response the Revue thomiste was founded in 1893, which tried to adapt scholasticism, the synthesis of Aristotelian reason and faith that Thomas Aquinas had achieved, to modern science. The 1884 formation of "The Societe de Saint Thomas d'Aguin," in Paris, was a response to the Aeternae Patris to study Christian philosophy. They attempted "to expose and refute modern errors from the double viewpoint of Christian philosophy and the natural 
and experimental sciences." 69 The revival of Thomism placed Thomas Aquinas' thought in the position of having to account for an entirely different world from the one for which it had been produced. Metaphysics had come first in Aquinas' thought. Neo-Thomists hoped that a revival of Aquinas' synthesis of reason and faith would supply the fundamentals necessary for a Catholic science opposed to 70

the modern atheistic science.

By using reason to attain to both natural and supernatural truth, Thomists claimed both to be objective realities.

An example of the efforts of Neo-Thomism to reconcile itself with the challenges of chemistry's "composition of bodies" illustrates the problems. The Thomist Ramiere, in the 1870's, explained that "in the case of substantial change the body retains its primary matter but changes its old form for a new one." The substantial change in the Eucharist was thus in accord with natural science. Even with the soul as the vital force, Paul posits that "this kind of concordism made metaphysics dependent upon physical theory."

This kind of reciprocal support between science and religion seemed to some Catholic Modernists as obscuring the true nature of both science and religion. Maurice Blondel (1861-1949) published responses to Maurras' 
position and that of the Neo-Thomists as part of his concern for what he called in 1907:

The present crisis, unprecedented perhaps in depth and extent--for it is at the same time scientific, metaphysical, moral, social and political--is not a "dissolution" (for the spirit of faith does not change), it is a purification of the religious sense, and an integration of Catholic truth.72

Reardon maintained that Maurice Blondel's view on the relation between science and religion integrated Conventionalist ideas with Blondel's own philosophy of 73

action. Catholic and non-Catholic contributed to the new critique of science that was a part of an "integrated and interdisciplinary" philosophical movement, which began in 74 the $1870^{\prime} \mathrm{s}$.

Conventionalism was the position developed by Henri Poincaré (1854-1912). In turn, the center of Poincaré's group was Emile Boutroux (1845-1921), a Sorbonne philosopher. The group also included Jules Tannery (18481910), the director of the science curriculum at the Ecole normale superieure. The new critique (or Conventionalism) was a reaction against the old positivism, seen as too 75

deterministic.

Turn-of-the-century conventionalist

philosophy asserted that:

Fundamental scientific principles are not reflections of the "real" nature of the universe but are convenient ways of describing the natural world insofar as they are not contradicted by observation or experiment.76 
Poincare's Conventionalism, which drew heavily from Emile Boutroux's philosophy of contingency and creativity, entailed, among other points, that: 1) There should be a rigorous interdisciplinary approach to knowledge instead of a rigid, authoritarian view that excluded the world of 1 ife as too unruly for the necessary degree of certitude, thereby reducing human experience to the level of the 77

simplest physical phenomena. Neither the mechanical determinism of Comte's disciples nor the historical determinism of German philosophy allowed "the world of science to coincide with the world of life." 2) For Boutroux, "each order of science implies postulates proper 78

to itself." 3) Against the old positivists, Boutroux argued that philosophy did not stop with the task of synthesizing the sciences; philosophy was a higher reason that united the natural world with "rational moral liberty 79 of action."

Poincaré began his intimate friendship and family relations with Boutroux, after Boutroux had outlined the above philosophical points in his 1874 thesis, The Contingency of the Laws of Nature. Although there are points of difference between Poincare' and Boutroux, Poincaré's Conventionalism also consisted of an opposition to the dogmatism of the positivist schools and Catholicism because both "deprive us of impartiality of judgment." 
strictly mechanical formulations of science according to poincaré, "fail to distinguish clearly between what is experiment, what is mathematical reasoning, what is convention, and what is hypothesis." Every law was only a provisional statement which would be replaced by a superior law, because the circumstances had been modified. Pointing out the role of social choices in determining our conceptions about knowledge, Poincaré held that "determinism presupposes liberty, since it is our free choice that we have become determinists."

As Boutroux's student, Blondel was schooled in Boutroux's view. Blondel agreed with the premise of the new critique in that he saw science and religion as two separate discourses "based on their own special conventions, into which a certain element of arbitrariness always enters." Blondel's judgment on scholasticism was the same as that of "the new criticism of old positivism." 82 Reardon concluded:

They [scholasticism/Neo-Thomism and old positivism] both suffered from the intellectualist error of seelng truth as imposing itself on man's mind like an external decree, regardless of his ability to relate it to his own experience, and failing to recognize the dimensions of creativity and human thought. 83

Whether the subject was science or religion, discourses were human productions with a subjective element. With Neo-Thomists and their scientific 
apologetics there was a fruitless effort to harmonize "the conclusions of the positive sciences with the dogmas of the Church" that was based erroneously on the "assumption that science is seeking to give a picture of reality whereas in fact science is using symbols functionally for pragmatic 84 a ims."

On September 8, 1907, the encyclical Pascendi condemned the theses that some Catholic authorities found offensive in Catholic Modernism. Dansette summarized the offensive aspects:

Agnosticism with regard to rational proofs; the doctrine of vital immanence, which derived religious truth from the individual need for faith and gave it no more than symbolic importance, attributing the origin of dogmas to the perception of God by the intelligence in man's innermost consciousness; attributing the origin of the sacraments to the need to give religion a tangible aspect and to make it known; and denying the place of the super-natural in history.85

This condemnation came after over 17 years of polemics over the relation between the modern scientific world and the traditions of Catholicism.

sutton concluded that the controversy centered on different ideas concerning "first, the relation between the natural and the supernatural (and therefore between politics and the realm of Christian religion), and, the very nature of the 87 Church." 
The Task In Common

The task in common for James, Renouvier, Bergson, Blondel and Boutroux was the defense of intellectual freedom against dogmatism. A moral philosophy that justified Ereedom, intellectual and/or personal, was required in a democracy where the individual person participated in decisions that effected society. The political and theoretical needs of democracy, the challenge to the meaning of 1 ife and God, and the intrusion of a rigid conception of science in philosophy needed to be resolved. The combined effects of the political, religious, social and philosophical questions were the issues with which James, Renouvier, Boutroux, Bergson and Blondel found themselves confronted. 
Notes

1

Thomas F. Glick, Ed., The Comparative Reception of Darwinism (Austin: University of Texas Press, 1974) 168.

2

Glick 182 .

3

G1 ick 187 .

4

Bruce Kuklick, The Rise of American Philosophy:

Cambridge, Massachusetts, 1860-1930 (New Haven: Yale University Press, 1979) 233.

5

Glick 175 .

6

James, Praqmatism 9.

7

William James, "The Mood of Science and the Mood of Faith," The Nation XIX 31 December 1874: 437 .

8

Glick 199.

9

GIick 187 .

10

James "The Mood of Science and the Mood of Faith"

437 .

11

Glick 188 .

12

Glick 197.

13

Glick $189,203$. 
14

Levi 91.

15

Levi 91 .

16

Levi 77 .

16

Levi 63.

17

William James, Essays in Pragmatism ed. Alburey Castell (New York: Hafner Press, 1948) 17, 26.

18

William James, "The Teaching of Philosophy In Our Colleges," The Nation XXIII 21 September 1876: 178 .

19

William James, The Variety of Reliqious Experience: A Study in Human Nature (1902 New York: Penguin Books, 1982) xxxvi .

20

John J. McDermott, ed., The Writings of

William James: A Comprehensive Edition by william James (1967 New York: The Modern Library, 1968) xx.

21

William James, "The Teaching of Philosophy In Our Colleges," The Nation XXIII 21 september 1876: 179 .

22

Ralph Barton Perry, The Thought and Character of William James 2 Vols. (Boston: Little, Brown and Company, 1935) Vol. 1, 534 .

23

Perry Vol. 1, 536 . 
24

Perry Vol. 1, 209,401.

25

William James, Collected Essays and Reviews

(New York: Longmans, Green and Co., 1920) 316.

26

James Collected Essays and Reviews 318 .

27

William James, Memories and studies (New

York: Longmans, Green, and Co., 1912) 330.

28

James Memories and studies 336.

29

Perry Vol. 1, 441 .

30

Roger Henry Soltau, French Political Thought in

the 19th Century (New York: Russell \& Russell, 1959) 171.

31

Harry Paul, "The Crucifix and the Crucible:

Catholic Scientists in the Third Republic," The Catholic

Historical Review LVIII Apr. 1972: 196, 197.

32

Soltau 252.

33

Charles H.C. Wright, A History of the Third

French Republic (1916 New York: Books for Libraries Press, 1970) 28 ; Soltau 266 .

34

Wright 40 .

35

Soltau 266. 
36

Wright 35 .

37

Soltau 267.

38

Wright 44 .

39

Wright 46 .

40

Wright 50 .

41

Wright 54 .

42

Wright 59.

43

Wright 73 .

44

Wright 189-191.

45

Wright $116,162$.

46

Wright 60 .

47

Frederick Copleston, S.J., A History of

Philosophy Vols. VII 1965, VIII 1967, IX 1977, Book Three (New York: Image Books, 1985) Vol. IX 80, 85.

48

Soltau 205.

49

W.M. Simon, "Comte's Orthodox Disciples: The

Rise and Fall of A Cenacle," French Historical studies IV.1 Spring, 1965: 43. 
50

Simon 44.

51

Soltau 214 .

52

Emile Boutroux, Science \& Reliqion In Contem-

porary Philosophy trans. Jonathan Nield (1909 New York: Kennikat Press, 1970) 63 .

53

Soltau 208 .

54

Soltau 211 .

55

Paul, "The Crucifix and the Crucible" 197.

56

Paul, "The Crucifix and the Crucible" 200.

57

Pierre Duhem, To Save the Phenomena trans.

Edmund Dolan and Chaninah Maschler 11908 Chicago: Midway Reprint, 1985) 283 .

58 Paul, "The Crucible and the Crucifix" 209-211.

59

Michael sutton, Nationalism, Positivism and

Catholicism: The Politics of Charles Maurras and French

Catholics 1890-1914 (London: Cambridge University Press, 1982) 1 .

60

Sutton 5,13

61

Sutton $14,16$. 
62

Sutton 24,27 .

63

Sutton 17,27 .

64

Sutton 20 .

65

Sutton $19,24$.

66

Sutton 2 .

67

Adrien Dansette, Religious History of Modern

France vol. II (New York: Herder and Herder, 1961) 310.

68

Dansette 297-8.

69

Harry Paul, The Edge of Contingency--French

Catholic Reaction to Scientific Change from Darwin to

Duhem (Gainesville: University Presses of Florida, 1979)

182.

70

Paul, The Edge of Contingency 183-4.

71

Paul, The Edge of Contingency 185.

72

Maurice Blondel, Letter on Apologetics and

History and Dogma presented by Alexander Dru and

Illtyd Trethowan (London: Harvil1 Press, 1964) 226.

73

Michael F. Reardon, "Science and Religious

Modernism: The New Apologetic in France, 1890-1913," The Journal of Religion 57.1 Jan. 1977: 49-50. 
74

Mary Jo Nye, "The Boutroux Circle and Poincaré's Conventionalism," Journal of the History of Ideas XL-1 January-March 1979: 119.

75

Nye 113.

76

Nye 108.

77

Nye 109-110.

78

Emile Boutroux, Natural Law in Science and

Philosophy trans. Fred Rothwell (London: David Nutt, 1914) $126-7$.

79

Emile Boutroux, "Du Rapport de la philosophie aux sciences," Revue de Metaphysique et de Morale XIX (1911) 424-29; Nye 115.

80

Nye 118 .

81

Nye 119.

82

Michael F. Reardon 57.

83

Michael F. Reardon 58.

84

Avery Dulles, A History of Apologetics (New York: Corpus, 1971) 204 .

85

Dansette 306 . 
- ZSZ uo77ns

$\angle 8$

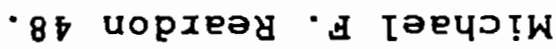




\section{CHAPTER I I I}

WILLIAM JAMES, CHARLES RENOUVIER AND HENRI BERGSON

William James took part in the movement to meliorate the divisions in philosophy that occurred with the break up of classical philosophy and to define science, philosophy and religion by the object man intended each to apprehend. The break-up of classical philosophy took many directions. According to Eastwood, James' philosophy falls within the 19th Century reversal of thought from the "outward, simple and universal" perspective of the Reign of Science (18501890) to the personal, "inward, concrete and particular, which reproduced the synthetic centripetal tendency of first "systematic attempt to apply the calculations of chance to a metaphysical question" (belief in God) and his aphorism, "the heart hath its reasons which reason knoweth not," informed the work of these philosophers of action.

Pascal's insistence on man's reliance on both the heart and mind in his consideration of the relations between faith and science, can be clearly identified in the work of James, Renouvier, Bergson, Blondel and Boutroux. In addition to the Pascalian elements, these philosophers can be classified as Neo-kantian on the basis of their 
central vision of human activity. Although each man's philosophy was unique, their response to the problems of absolutism, materialism, scientism and rationalism, justifies classifying them, as a group, as philosophers of action. The inclusion of william James in this group is based on James' adoption of Charles Renouvier's conception of free will, Henri Bergson's defense of the continuity of experience against the logic of identity and Maurice Blondel's technical presentation of his philosophy of action which was consonant with James' development of the metaphysical explanation of the nature of truth in terms of "becoming." James, relationship with Emile Boutroux was the summation of James' philosophy and Boutroux was the force that connected these five philosophers of action.

The variants of "Kantisms" require that the origin of the term pragmatism as used by kant be kept in mind to orient the connection between Kant's use and the scholars in question, who are called philosophers of action on the basis of the following precise connection:

I call pragmatic the practical rule (law) derived from happiness as its moving principle (a rule of worldly wisdom)... It is based on empirical principles because only from experience can I know what inclinations there are to be satisfied and which are the natural causes which might procure their satisfaction... When I do not know with certainty the conditions under which an end may be achieved, I call the accidental belief, which is, however, the basis for using certain means, 
the aspect of whatl as a free agent he can accomplish in the world.3

Kant's Critique of Pure Reason specifically designated a practical rule in response to the needs criticism unearthed.

James contemporary pragmatism developed as a criticism of Neo-Hegelian Idealism; it was a "revaluation from within." Caponigri correctly stated the case by emphasizing that pragmatism sought an "intellectual reconstruction" to accommodate the new problems in intellectual life brought by the newer sciences. The term was taken up by so many that Lovejoy was able to designate "Thirteen pragmatisms" in a 1908 article in the Journal of Philosophy. Caponigri isolated "certain constants" characteristic of pragmatism. The variations have in common: 1) a metaphysical aspect, which was "an effort to construct a viable theory of truth and of reality;" and, 2) a methodological aspect, which was an "effort to formulate a theory of meaning."

Both absolute idealism and rigid positivism were rejected by these philosophers of action. Positivism was publicized as an empirical philosophy and a scientific displacement of metaphysics. Comte's disciples defined positivism in a variety of ways. The most popular versions left out his spiritual thought. Positive knowledge was the goal. The scientific method was seen as objectivity itself 
and there was no need to ask about any existence outside scientific expression. The generalization of this attitude convinced many that questions about God, existence, and immortality were denied objective confirmation in advance. Advocates of positive knowledge put their faith in sociology for knowledge about human affairs and conduct. Psychology, as a science of the individual, was in its infancy. James encouraged psychology to break away from philosophy and be organized to study physiological and psychical operations by scientific method. What remained outside of all of these sciences was an understanding of reason that was capable of answering the question of "why" things happen at all. To opt for absolute idealism that deduced a total, logical system was, of course, limiting oneself to logical things.

The absolute separation of the empirical and the ideal with their arbitrarily exclusive nature seemed incapable of admitting life as it was lived. Philosophic opinion was in the form of the uncertain situation for which Kant had recalled the term "pragmatic." For according to kant, to be wise in human life there was a need for knowledge based on empiricism and futurism. Responding to the need for a moral philosophy to guide human action, these five philosophers of action each developed a system of knowledge derived from the 
arrangement of three perspectives-empiricism, futurism and spiritualism. In accordance with Kant's rule, they each suggest a theory of truth and a method by which to prove its meaning.

James' Pragmatism differed from others, such as Peirce's, which was primarily concerned with scientific knowledge. Concern with all human experiences attach James to these French philosophers and it attachs them all to a pragmatism in the spirit of kant. Capronigri summarized Kant's conception of pragmatism: "The term refers to an insight into the entire situation of man in the world of experience and the way in which he makes his way in it." It was a term for the perspective of the human point of view. Capronigri made the point well by stressing the dynamism and inclusiveness of James' concern with action in scientific inquiry, moral action, and religious affirmation. For James, man acts with a view towards something.

James' initial reaction against scientism, or "vicious intellectualism," was stimulated by much the same personal response common to many. It was a shock to personal conceptions of one's own identity for it to be asserted that mechanism was man's essential nature. Individual identity had been comprised of considering that man was special. The fact that man had a responsibility 
and had special abilities to achieve in life, gave life meaning. Man's will and reason worked together. To take away those aspects that were special to man, was to alter the conception that people had of themselves as individuals and left them unmoored altogether. These philosophers of action each state their philosophic motive as the desire to answer the question of the meaning of life in a way that accommodated the private and social needs of a scientific age.

James: His Thought and Philosophical Problems

Philosophy does not come full-blown, it is made. James' philosophy began with the inheritance of his father's intellect, his generously democratic perspective, his essentially spiritual nature, his courage, and his father's despair. Henry James, Sr., had thoroughly imbued William James with Emmanuel swedenborg's $(1688-1772)$ doctrines. William James was always concerned with the "point of departure" for Swedenborg's doctrines that also interested kant; namely, "The conviction of the existence of a constant mutual influence between the mental and the material, between the spiritual and the natural." ${ }^{8}$ The effort to unify these parts accounted for the despair of both father and son.

Although his father had a pervasive effect on the formation and orientation of James' intellect, there were a 
number of others to whom James readily acknowledged his intellectual debt. Among those James singled out were Charles Renouvier and Henri Bergson. James' contacts with Charles Renouvier (1815-1903) and his works, began in 1868, through his reading of the introduction of L'Anneé philosophique. 9 James read Renouvier's Deuzième Essaie in 1870, after several years of personal crisis that included depression and despair about the meaning of his 1 ife.

Referring to the despair he had experienced at this time, James told his son, Henry, that the experience attributed to a "Frenchman" in The Varieties of Religious Experience (hereafter referred to as Varieties) was actually James' own. James recounted there his encounter with the idea of capricious fate. He was unable to ignore "that pit of insecurity beneath the surface of 1ife." James' period of despair reached a turning point as recorded in his April 30, 1870, diary entry:

I think yesterday was a crisis in my life. I finished the first part of Renouvier's 2nd Essay and saw no reason why his definition of free-wil1-'The sustaining of a thought because I choose to when I might have other thoughts'--need be the definition of an illusion. At any rate I will assume for the present--until next year--that it is no illusion. My first act of free will shall be to believe in free will.10

The agnosticism of positivism and the rigidity of Absolute Idealism left James in a metaphysical quandry. 
James vowed to "abstain from speculation and voluntarily cultivate the feeling of moral freedom" by reading as well as acting. He felt that later he might be able to take up metaphysical study and skepticism "without danger to my powers of action. For the present, then, remember: Care little Eor speculation/much for the form of my action."

November 2, 1872, James wrote to Renouvier to thank him: "Thanks to you I possess for the first time an intelligible and reasonable conception of freedom." ${ }^{12}$ James placed himself on the side of free will, which required that there be more than one option, in 1870, before he got his first professional job as instructor of anatomy and physiology at Harvard in 1873. His reason for living could reside in the fact that he had a duty to fulfill that was not automatically assured; he could affect his world. The correspondence between James and Renouvier and the study of James' works led Perry to the conclusion: "Renouvier was the greatest individual influence upon the development of James' thought."

Charles Renouvier's conception of the will as free and its role as the central truth on which moral philosophy should be built, became James' own. We must understand the problem of free will within Renouvier's thought and context in order to understand in what ways James was carried into participation with the French movement of intellectual and 
spiritual integralism that developed during the last half of the 19th Century.

Charles Bernard Renouvier (1815-1903) studied at the École Polytechnique at Paris at the time Comte was there as an acting instructor in mathematics. Although an influential philosopher through the publication of books and journals, Renouvier never occupied a place in the French educational system. He was a believer in freedom and in the French Republic. In 1848 he published Manuel republicain de l'homme et du citoyen, Republican Handbook on Man and the Citizen), and he continued his political thought through the pages of the journal, La Critique philosophique begun in 1872 .

Comte's claim to objective truth by his positive method and his intrusion of science into philosophical discourse, not only failed in its consideration of psychology and ethics, it also brought a reaction against his rigid conception of knowledge by Charles Renouvier. Renouvier's philosophy, called "Personalism" or "NeoCriticism," claimed to carry Kant's work beyond kant as applied to the contemporary situation.

Copleston differentiated Renouvier from kant in the following ways: 1) Renouvier objected to the "thing-initsele" and held that the phenomenal and the real were the same. 2) Renouvier's categories were all derived from 
experience of relation, i.e. nothing could be known except as related; these included "number, position, becoming, quality, causality, finality or purposesiveness and personality," none of which could be deduced "a priori by transcendental method." 3) Renouvier maintained there was no "distinction" between knowledge and belief. In all knowledge the "intervention" of the will meant there was a personal element, although reason or will could dominate according to the activity. Freedom was a "datum of moral consciousness;" it could not be demonstrated by reductionism. "For Renouvier, the concept of rights has meaning only within a social context;" however, individuals had moral duties. For "there is a relation between what he is and his higher or ideal self and he is obligated to realize his higher self in his character and conduct." For Copleston, much in James resembled Renouvier's regard for personality "as the highest category and as the developed form of the abstract category of relation."

Eastwood posited that kant "vindicated" practical reason at the expense of pure reason, and saw Renouvier and James as Kant's heirs in the sense that they both sacrifice the "age-long demand for an intelligible universe" to the "ideas of liberty and of the individual." 17 Wahl, in The Pluralist Philosophies of Enqland and America, placed Renouvier as a pragmatist, 
which Wahl defined as one "who takes vital necessities into account and wills the power to act." 18 Based on the action that follows the will Renouvier's rationally practical beliefs included the "moral postulates of human liberty, the existence of God and individual immortality." Like Pascal, Renouvier found that the man of science, faith, morals and religion could not be separated.

For Renouvier, the will presupposed intelligence and passion, which meant that pure and practical reason could not be separated as kant had done. 20 There was no absolute necessity independent of will. There was no autonomous authority to be known outside of the individual. The highest possibilities for man depended upon the relation achieved between man and his environment. Renouvier continued Kant's line of thought by extending the fundamental role of belief in both pure and practical reason, making both subject to the will, thereby crossing the line kant had drawn between the objective and the subjective.

Renouvier called himself a philosopher of action because he found the fundamental truth of man in the action of will. Man's will was free and could "break the logical continuity of a mechanical series and be the initial cause of another series of phenomena." 21 Contingency and liberty could not be "excluded from the world of concrete 
phenomena." On this basis, both Renouvier and Boutroux critiqued the idea of absolute necessity. The actuality of subjectivity meant free will; the individual was not forced by an external authority to decide or behave in only one particular fashion. It meant the possibility of pluralism in the perceptual and conceptual world and the interaction between the two. These philosophers of action held these views thereby bringing Kant's idealism into a new relationship with their contemporary thought. Crawford placed Renouvier's ethics of duty, as the "kernal of his philosophic thought;" that is, morality "depends upon responsibility and responsibility depends on freedom." His political theory was his philosophy in action. Its applicability to the Third French Republic's political problems reveals its humanistic orientation.

As noted in Chapter II, the Third French Republic found its philosophical position uncertain. The opposition position of the Liberals during the two preceeding regimes had left them without a philosophy because they had "only wanted freedom for themselves, unconcerned with its general extension." They had no philosophy of individualism, of individual rights valid "equally for all classes and individuals," because they were absolutists for their own interests. For Soltau, Renouvier was the "One writer there is who may be said so to have grasped the essentials of 
individualism as to base thereon a true philosophy of Liberalism."

$$
23
$$

Renouvier's political theory provided the liberal philosophy needed. French Liberalism proved itself inadequate to resolve the religious problem because it was seen in terms of two irreconcilable forces. On the other hand, for Renouvier society had two bases; 1) the individual, and 2) the fact of human solidarity; "each man [was] as an end in, and to, himself, equipped with the means of realizing that end, with the help of others if needs be, and if possible."

The individual and social were inextricably involved. Renouvier insisted on the moral progress of the individual first because moral development was "both the basis and the end of all society, and the sole criterion of its rightness, moral progress being the only real form of progress." In Individualism, the person's conscience was the basis for conduct. In place of Comtism's external, objective view, Renouvier's philosophy was trained on the internal, subjective concern of the individual's needs for action in everyday affairs and personal life, guided by a morality that sought to make the world progress.

From 1897-1900, Renouvier's conceptions of the individual/social relationship slowly built up a republican response as the Dreyfus Affair became a national crisis. 
Because Dreyfus was a Jewish military officer, religious, political and social issues were involved in finding guilt or not. As the nation worked its way through the issues, the idea of strict justice "for the individual" as an essential "condition of any social order" gained advocates. Many republicans came to the conclusion "that clericalism and militarism of a certain type had become real dangers to a Republican system."

James adopted Renouvier's conception of free will with its focus on human action as a critical test of contemporary problems. In an 1873 notice in The Nation, James called attention to La Critique Philosophique and the doctrines of Charles Renouvier and their differences from British Empiricism. Renouvier's originality was in positing the "possibility of absolute beginnings, or of free will." Renouvier made an act of self affirmation the heart of philosophic thought. Liberty was the center of the system, which made it a moral philsophy. Republicanism was the "political corollary of free will in philosophy." An act of liberty was central to Renouvier's conception of free will.

In an 1876 article in The Nation, James gave further specification of the merits of Renouvier's thought over that of the English philosopher Bain. The differences between Renouvier and the British were: 1) Renouvier did 
not consider a fact, or phenomenon "apart from its group, law, or function." Man's acts were at times "original commencements of series of phenomena, whose realization excludes other series which were possible." ${ }^{28}$ For Renouvier, "the minimum of faith produces the maximum of result." Renouvier praised James for his "masterly" account of the "new empiricism" that departed from the "empiristic, associationist and deterministic doctrines of the English on questions of substance, certitude and free will."

James noted that the confusion in philosophy was a result of the philosopher concealing his motives: "The reasons ostensibly put forward by a philosopher formed but a small portion of his real premises." James directed the reader to "the masterly remarks of Ch. Renouvier in the acknowledgement of the subjective element in philosphy was extended to science, morals and religion.

James saw Renouvier as furthering Humean phenomenalism, i.e. experiential facts exist, and James adopted Renouvier's conception of phenomena as having meaning as relations within a given context. James' reading of Renouvier's Deuxième Essais gave him his fideism, his "defense of voluntary belief." It was not that will could act directly on the body, rather, will worked by virtue of dwelling on an idea, which became 
expressed in action. By basing their philosophies on belief, both Renouvier and James based their philosophies on a subjective basis. 33

Man's individual value rested on the question of freedom. "Are We Automaton" and "Reflect Action and Theism" (1881) show Renouvier's lasting influence as therein James upheld "thinking-feeling-consciousness" as a "process of interaction." He located moral purpose and causal explanations in operations of the mind and brain. James espoused Renouvier's argument for freedom, placing them both in the history of French subjectivism, voluntarism and fideism: "thinking must be free if it is to be either true or Ealse; so that it can mean nothing to discuss the question of freedom unless one is free to affirm or deny it." 35

Perry included Renouvier's position as one held by a number of professors in France who were fighting "traditional rationalism and positivism." Important for James' pluralism was Renouvier's view "that the whole is an expression of the interaction of originally independent forces." There was a unity, a whole of related entities, but the unity did not predetermine the many. Perry maintained that it was from this idea that James grounded his position of the "priority of part to whole." James and 
Renouvier join freedom and discontinuity and the need for a 36

"practical spirit in philosophy."

The question of free will versus determinism was the main question of interest to James for the first two decades (1870-1890) of his professional career. This period corresponded to his teaching of anatomy and physiology and the writing of The Principles of Psychology (1890). From 1890 onward, James concerned himself with the metaphysical problems encumbent upon pluralism.

In Some Problems of Philosophy, the last text prepared by James and published posthumously, James again acknowledged his debt:

He [Charles Renouvier] was one of the greatest of philosophic characters, and but for the decisive impression made on me in the seventies by his masterly advocacy of plurallsm, I mlght never have got free from the monistic superstition under which I had grown up. The present volume, in short, might never have been written. This is why, feeling endlessly thankful as I do, I dedicate this textbook to the great Renouvier's memory. 38

The inspiration of Pascal and the influence of Kant for both Renouvier and James continued to inform James' works and provided the germinating seed for his Pragmatism. James applied Pascal's "Wager" in his 1896 essay, "The Will to Believe." James argued that both science and religion had in common the fact that ultimate actuality depended on the action of belief. Hypotheses were formed according to ideas of what was potentially true. It was only on this 
basis that man acted at all. The consequences of acting on these beliefs determined their truth. Hypotheses were to be based on ideas drawn from empirical datum, which included the effects of relations between all aspects of concrete experience. James believed an optimistic faith could be based on an empiricism that included relations as phenomena. Kuklick aptly called James' pluralism, "voluntaristic idealism."

By stressing the role of belief, James sought to convince the scientists and philosophers in the audience of the common element of belief based on the requirements of action in all inquiry. In view of the information being supplied by the sciences, philosophers were encouraged to look to concrete experience to understand the facts produced in physiology, psychology, and biology. Their efforts were to be directed towards explaining them in some sort of unified frame, without arbitrarily excluding parts of the multiplicity of human experience. In particular, James was concerned that English Empiricism was tending towards determinism.

James' concern was based on the fact that many empiricists found no basis for absolute certainty except "momentarily" in the immediate presence of particular facts. For them, isolated facts were susceptible of objective knowing. Relations between facts were not susceptible of direct knowledge as they were secondary 
effects of association and habit. A world view confined to the assertion of particular facts, left life as it was individually lived as "so much dust." James believed it was possible to develop a pluralistic, open-ended, yet comprehensible view of the world that could serve as a warranted guide for life.

In contradistinction to the direction empiricists were taking, the absolute idealists erred by the opposite extreme. In "The Function of Cognition" James objected to the Hegelian School for trying to "shove simple sensation out of the pale." They considered "A perception detached from all others, being out of all relation, has no qualities--is simply nothing. We can no more consider it 40

than we can see vacancy." For them, all was concept. Thought, as the relations of knowledge, was considered a better $k$ ind of consciousness than one of feelings. "Their all in all is mental life." on the other hand, James maintained that percepts were primary realities. Their existence prompted the naming of an object and showed that cognition functioned as a knowing something that "does exist elsewhere than in it." 41 James was clearly opposed to the truth of both absolute objectivity and extreme dualism, which unalterably separated the knower from the known and placed the idea of something as more real than the thing itself. 
Returning to "The Function of Cognition" as he collected the essays he wanted bound together as a statement of his metaphysics in 1909, James noted that "The reader will see how much of the account of the truthEunction developed later in Pragmatism (1907) was in this 42

earlier article." According to James, he "distinctly asserted" in 1884 :

1) The reality, external to the true idea; 2) The critic, reader, or epistemologist, with his own belief, as warrant for this reality's existence; 3 ) The experienceable environment, as the vehicle or medium connecting knower with known, and yielding the cognitive relation; 4) The elimination of the 'epistemological gulf,' so that the whole truthrelation falls inside of the continuities of concrete experience, and is constituted of particular processes, varying with every object and subject, and susceptible of being described in detail.

The defects of this earlier account: 1) The imperfect development of the generalized notion of the workability of the feeling or idea as equivalent to that satisfactory adaptation to the particular reality, which constitutes the truth of the idea. 2) The treatment, on page 151, of percepts as the only realm of reality. I now treat concepts as a co-ordinate realm. 43

In 1884, then, he had not worked out his theory of the function of ideas. The truth-relation was asserted as within concrete experience. However, explaining how it worked was before him.

In the 1897 Preface to The Will to Believe, James' noted his metaphysical position and his objections to the position of other philosophic views. "Ever not quite" was 
James final word on discovering absolute unity between all the facts given prima facie in the world; the world was a 44

pluralism. In this 1897 presentation of his philosophic "attitude," James objected to rationalists and "half-way" empiricists such as, positivists, agnostics and scientific naturalists because they were monists, they believed in an absolute unity. They believed "That the world could appear as an absolutely single fact." 45

James made a point of differentiating his philosophy from both absolute idealism and empiricists who posited a closed system. He would call his philosophical position Radical Empiricism, defined as: "This is pluralism. He who takes for his hypothesis the notion that it is the permanent form of the world is what I call a radical empiricist." For James, pluralism was to be found in nature, religion and morals; there were real beginnings and real ends. The old empiricisms, those he called "halfway," should adopt a radical view and stop trying to "overcome or reinterpret" the common-sense given plurality into a grand scheme.

For James, "Real possibilities,...a real God, and a real moral life, just as common-sense conceives these things, may remain in empiricism as conceptions." However, James had not formulated his explanation of the relations between concepts and percepts, between mind and body. 
James' essay "Philosophical Conceptions and Practical Results" (1898) marked the beginning of the pragmatic movement as James applied Pierce's conception of pragmatisn to religion. James proposed the question, "Is matter the producer of all things, or is a God there too?" The answer was to be obtained by the rule that the meaning "of any philosophic proposition can always be brought down to some particular consequence, in our future practical experience, whether active or passive."

James' Gifford Lectures, delivered in 1901-02, were published in Varieties in 1902. In Varieties, James applied pragmatism to the religious experience to ascertain what could be asserted about religious experiences based on their consequences. James wrote Varieties out of the conviction that the religious life as a whole was man's 48 most important function. He was interested in the private experience. He asked the audience to take the meaning of religion as:

...the feelings, acts, and experiences of individual men in their solitude, so far as they apprehend themselves to stand in relation to whatever they may consider the divine. Since the relation may be either moral, physical, or ritual, it is evident that out of religion in the sense in which we take it, theologies, philosophies, and ecclesiastical organizations may secondarily grow. 49

In the postscript in Varieties, James briefly stated his philosophic position and promised to elaborate in a 
later work. In the Postscript, James divided thinkers into "naturalists and supernaturalists;" and, he divided the latter into "universalistic supernaturalism" and the "crasser, piecemeal" sort of supernaturalism, allying himself with the second variety. James set forth his religious and metaphysical over-beliefs, which admitted: 1) The ideal and the real worlds mix. 2) The ideal region could be counted as one of the "forces that causally determine the real world's details;" an individual in communion with the "Ideal" brings new force into the world. 3) There was a power "other and larger than our conscious selves," concerned with the personal details of individual lives. 4) "It might conceivably even be only a larger and more godlike self." 5) The problem of universalistic conceptions, such as Transcendental Idealism, was in seeing "A world of fact!--an entire world is the smallest unit." James declared his belief in a powerful being and in a "spiritual relation between this being and ourselves." Furthermore, the "direct action of this being upon the details and the whole of our universe" was asserted. However, James' conception of the action of this being excluded any idea of coercive necessity.

James concluded that the relation between religion and "supernormal memory and cognitions" was through mysticism. For James, feeling and reason went together, 
but there would be no religion if it depended on "contemplative reason;" non-rational intuitive processes were necessary. These determined our activity and reason 52 cooperated.

James' assertions about spiritual experiences were Eirm. However, he did not have a complete metaphysical explanation that harmonized the various questions encumbent upon philosophy. As noted, looking back in 1909 on his 1884 essay, "The Function of Cognition," James said that it was not until Pragmatism (1907) that he changed his position and was able to "treat concepts as a co-ordinate realm" of reality. Admitting concepts and percepts as "coordinate" realms of reality left him with a troublesome dualism. Between 1900 and 1910, James concentrated on formulating a non-dualistic metaphysics.

Working from his adoption of Renouvier's conception of free will, from 1900 to his death in 1910 James developed the pragmatic rule into a theory of meaning with its corresponding metaphysical position of radical empiricism as a "non-dualistic formulation of the canvass of experience." During this time, his association with Henri Bergson helped James clarify his thought and connected him further with these philosophers of action. Perry concluded that Henri Bergson (1859-1941) was "the most important philosophical and personal attachment 
of James' later years." Both James and Bergson were interested in biology and the questions about man's role in the evolutionary process. What was the place of mind, imagination, and creativity? As Levi's analysis showed, Bergson's naturalistic explanation "of the persistence of the anti-intellectual in experience" was also a "pragmatic 54 argument for religion and myth." It was this perspective that Bergson and James shared.

Bergson's Essai sur les donnees immediates de la conscience, translated as Time and Free Will, was published in 1889, and read by James in 1889. Bergson's Matiere and Memorie (Matter and Memory) was published in 1896, and read by James in 1896. James reread both books in 1902 and commented: "Nothing in years has so excited and stimulated my thought. Before I couldn't understand Bergson--now Bergson brings things into a solution from which new crystals can be got."

$$
55
$$

In 1903, James expressed his frustration that he had not had the time to write his book on metaphysics. His mind was "working on the infernal old problem of mind and brain, and how to construct the world out of pure experience." The rereading of Bergson in 1902 had stimulated his thinking. James was sure that a systematic account of his philosophy of pure experience could be written; "his system shall be a genuine empiricist 
pluralism." He would resolve the problem of dualism by pluralistic empiricist tenents.

In his "Syllabus of Philosophy 3 (1902-03)," James presented a summation of his thought up to that time. A reading of the syllabus reveals James' struggle to organize the aspects of his thought in order to be able to write a book on his metaphysics. James presented the justification for the following views: 1) "'Pure Experience' agrees with common sense: our various minds "terminate" at percepts (physical things), which they experience in common." 2) The absolute unity of the world was a "sterile" understanding of the word "system." After the fact, it applied even to a chaos, as "systematically interadapted to that effect," and 3) "Tychism as an ultimate hypothesis. Chance, freedom" were given in the 57

world as it comes. James looked to common sense in order to negate closed conceptions of reality.

In his "syllabus," James also made his case for a philosophy that included phenomenal relations and ideals. In the case of relations, he listed forms of consciousness of transition: "continuity, activity, causality, change, development, help, hindrance, fulfilment, etc." Regarding ideals, the originals of all of these were "subjective aspects of experience." His conception of relations and ideals derived from tychism based on free will. James 
choose to justify tychism (chance) on three grounds, which reflect his overall concerns:

I. Scientific: No concrete experience ever repeats itself. II. Moral reasons: Tychism, essentially pluralistic, goes with empiricism, personalism, democracy, and freedom. It believes that unity is in process of being won. Tychism and "external relation" stand or fall together. They mean genuine individuality. III. Metaphysical reasons: Tychism eliminates the "problem of evil" from theology. It has affinities with common-sense in representing the Divine as finite and avoids Monism's doubling-up the world into two editions. For Tychism, things come in instalments, causing change. Continuous change would give us the completed infinite. Time and space may be infinite, the "quantity of being" is finite. Time and space may be infinite without contradicting $\log$ ic. 58

With tychism, God need not be held responsible for evil. However, continuous change according to chance made the world precariously chaotic. The relation between mind and matter required clarification in order to conceive of guides for effective action.

Still working on his metaphysics, in 1904 James outlined a proposal for a philosophy of pure experience. James wanted to overcome the separation that had occurred throughout the history of philosophy of the subject and its object. For James this was an artificial conception of a dualism that did not exist if the cognitive relation was understood correctly. By "pure," James meant that experience was neutral. There was a general "stuff prior to the object and the subject distinction," its mental or 
physical being was determined by which "group of associates" we tended to connect it with. "Pure experience was sensation, prior to mind-matter distinction. His was a universe that seemed chaotic, where no one connection ran through all experiences. There was no one single entity nor place that could be considered the center capable of knowing everything at once. Pure experience was the "immediate flux of life which furnishes material to our later reflections with its categories."

James concluded in 1904 that a philosophy of pure experience seemed to harmonize best with radical pluralism, novelty, indeterminism, moralism, theism and humanism. At this time he was not sure if all of these doctrines were necessary; the points of difference were so many that it could only be built up by contributions of "many cooperating minds." 61 At the time of his death in 1910, James had kept all of these doctrines except theism, which was acceptable but did not rule out panpsychism. His call for many cooperating minds occurred just at the time of his recognition of the likeness between his thought and Bergson's.

James wrote Bergson in 1902 congratulating him for his "conclusive demolition of the dualism of object and subject in perception" in Bergson's Time and Free Will. In 1903, James expressed confidence that Bergson's philosophy 
of "pure experience" could be worked out with the hope that it would help reconcile the opposition of the philosophic 62 schools towards each other. James also told Bergson that he agreed "thoroughly" with Bergson's "critical points" in his 1903 Introduction to Metaphysics, which James had read in the Revue de Métaphysique et de Morale. After reading Bergson, James applied himself to the questions of coconsciousness and causality.

The questions of co-consciousness and of the relations of what was "possible" needed to be worked out. These questions, of unity and causality, were difficult for a metaphysics of empiricism, like James', that allowed no recourse to trans-empirical explanations such as an "Unknowable" or intellectualistic conceptions of an "Absolute Mind." The dilemma was expressed as the problem of the relationship between the "One" and the "Many." If all things were a unity (the "One") then the world was a closed system and its individual parts (the "Many") had their course predetermined for them. This attitude led to what James called a "moral holiday" because the end result of man's life was fixed. IE there was a trans-empirical perfect unity, or God, how to account for evil remained a problem.

His thought on co-consciousness challenged the position he had held in The Principles of Psychology 
(1890). James had maintained that each field of consciousness was indivisible. However, in his 1905 article, "How Two minds Can know one Thing," which sought to explain the relationship between mind and body (or idea and object), James concluded that the same object could be known by two knowers. This meant that an identical part could be in two fields of consciousness. "The fields are decomposable into parts, one of which is common to both." He had to overhaul the "whole business of connection, confluence, and the like, and do it radically."

For two and one-half years, beginning in 1905, James kept a notebook of over 300 pages in which he tried to work out his basic problem, as Perry put it, of how to conceive of experience as able to retain two sets of properties "composing both the immediate and the transient life of the subject and the stable world of common objects." That is to say, James still had to work out the relation of concepts to percepts.

After reading Bergson's L'Evolution creatrice in 1907, James began to conceive of a way to explain coconsciousness by altering his conception of tychism as necessary for free will. James wrote to Bergson:

The position we are rescuing is "Tychism" and a really growing world. But whereas I have hitherto found no better way of defending Tychism than by affirming the spontaneous addition of discrete elements of being (or their subtraction), thereby playing the game with intellectualist weapons, you 
set things straight at a single stroke by your fundamental conception of the continuously creative nature of reality. 66

In a letter to James Ward in 1909, William James further clarified his new view:

None of my students became good tychists! Nor am I one any longer, since Bergson's synechism has shown me another way of saving novelty and keeping all the concrete facts of law-in-change. Giving up the logic of identity as the means of understanding the essences of concrete things,... we put the world of concepts in its definite and indispensable place; we allow novelty to be... Not tychism then, but synechism [continuity) (if we must talk Greek) is the solution. 67

James abandoned the "logic of identity," which held that the "units of reality" were either identical or not, and adopted Bergson's real time of "duration." James was then able to resolve the two problems of his metaphysics of pure experience: "the status of possibilities and the shareability of pure experience--both reduced to one question: what precisely was the nature of pure experience?"

James presented $h$ is experiential metaphysics in $\underline{A}$ Pluralistic Universe (1909). It was designed to meliorate the division between mind and matter by explaining their relationship. Concepts cut up the movement of life. Reality and rationality were not "in perfect agreement." Men act on concepts projecting them into the future. Concepts were practical, but had "no theoretic value" because they gave no insight into "the inner life of the 
69

flux."

Sensational

experience

gave the

causal

connection.

Metaphysics could go where conceptual science could not. As philosophers of action, James and Bergson were interested in process, in life as evolving. Life as continuous creative movement meant each moment was selftranscendent. Abandoning the conceptual, or "discursive form," allowed the continuity of real experience in its manyness-in-oneness. In reality, the relations of things, cause and effect, time and space, were "integral members of the sensational flux." 70

Following Kant's postulate, James' critique of the principles of knowing led to the substantiation of a metaphysics of pure experience with its "doctrine of compenetration" and his assertion of a philosophy of action, which viewed life as a process of creative becoming. The relation between the one and the many, the subject and object, concept and percept, was not one or adding and substracting in a continuous change. Each pulse of experience flowed into the next, "the first develops into the second, the second emerges from the first...novelty then seems natural and reasonable, like the fulfillment of a tendency." 71

In his notebook of answers to the critisms of his doctrine of "pure experience," James concluded: "The 
constitution of reality which I am making for is of [the] 72

psychic type." Kant had placed the self outside of time and space in order to free it from the necessity of the laws of nature. By critiquing pure reason, James followed Renouvier's lead in eliminating the absolute division between the external and the internal (or personal) and placed the reality of both in the environment and the self in the compenetrating movement of experience. The prestige of reason rested in its pragmatic use in the business of Iife, which should be the moral progress of man. James' philosophy of action was an intrinsically willed humanism that included God and man in an open-ended, selftranscendent process of becoming in concrete experience where the unity was in the making.

As men of science, both James and Bergson believed that our interest in physics was a legitimate activity and the method of mathematics suited physics as its object. However, equivalencies (the "equal" sign in mathematics on which the logic of identity rested) were constructed conventions that suited the very slow change of physical 73

nature. As noted earlier, this conception was put forth in Conventionalism. For both James and Bergson the basis for rationality in metaphysics, whose object was more irregular than physical nature, could not be formally logical if we were to understand the conduct of freedom. 
The role of irrational impulses in life was too abundant and required a method constructed for the general nature of experience manifest in action.

Although Bergson's philosophy was considerably different from James' as a whole, they both worked to resolve the conflict between science and religion because theology and philosophy were both concerned with ultimate 74

questions. Their efforts fall within the movement of their time to delineate fields of inquiry and to 1 iberate philosophy so that it could develop a metaphysics that allowed the philosopher to approach, with equal ease, the various conceptual frameworks employed in each discipline.

Both James and Bergson saw themselves as taking part in an identifiable movement. Bergson maintained that he and James shared a desire to work out a philosophy "more genuinely empirical, closer to the immediately given." Bergson and James were "attached" by way of their mutual insistence that reality is continuous and "open-ended." Reacting against Comtism's proclaimed "end of metaphysics," both Bergson and James founded a metaphysics on the conscious experience of continuity. Emphasizing continuity corrected the "abstract timelessness of the intellectualistic view." 76 Bergson emphasized that the most important $l i n k$ between $h i m s e l f$ and James was the "movement of ideas which has for some years been in 
evidence everywhere and which arises from causes that are 77

general and profound." The task in common to James and Bergson was to "reconcile the partial truth of conceptual knowledge with the fuller truth of immediacy." 78 For both, the compenetration of reality before conceptualization meant that man was conceived as knowing an object from the inside by intuition and an act of "intellectual sympathy."

A Pluralistic Universe and Some Problems of Philosophy entail new elements developing in James' thought as he conceived the implications of a life of becoming, common to all things, where action towards the ideal form of human life was within empirical reality. The next task is to see how his pragmatic method substantiated his metaphysics of pure experience based on the evolutionary conception of the creative impulse common in mind and matter. 
Notes

1

Dorothy Margaret Eastwood, The Revival of Pascal:

A Study of His Relation To Modern French Thought (Oxford:

The Clarendon Press, 1936) 22; Perry, vol. 2, 380.

2

Lucy Shepard Crawford, The Philosophy of Emile

Boutroux: As Representative of French Idealism in the

Nineteenth Century, diss., U Cornel1, 1924, 158644 (Virginia: Indiana Press, 1924) 4, 11, 69.

3

A. Robert Caponigri, Philosophy From the Age

of Positivism to the Age of Analysis (Indiana: University of Notre Dame Press, 1971) 44.

4

Caponigri 44.

5

Caponigri 45 .

6

Caponigri 50 .

7

Caponigri 45 .

8

Emile Boutroux, William James, trans. Archibald and Barbara Henderson (New York: Longmans, Green, and Co., 1912) $2-4$.

9 Perry, vol. 1, 654. 
10

Gay Wilson Allen, William James (New York:

The Viking Press, 1967) 166, 168.

11

Allen 169.

12

El izabeth Hardwick, ed., The Selected Letters of

William James (1960 Boston: Nonpareil Books, David R. Godline Publisher, 1980) 89.

13

Perry, vol. 1, 655 .

14

Copleston, vol. IX, 138-9.

15

J. Alexander Gunn, "The Philosophy of Emile Boutroux," The Monist XXXII.2-Apr. 1922: 170 .

16

Copleston, vol. IX, 140-5.

17

Eastwood 23.

18

Jean Andre Wahl, The Pluralist Philosophies of

Enqland \& America, trans. Fred Rothwell (London: The Open Court Company, 1925) 75 .

19

Th. Flournoy, The Philosophy of William James,

trans. Edwin B. Holt and William James, Jr. (London: Constable \& Company Ltd., 1917) 39.

20

O. Hamelin, "Volonté, Liberté, Certitudé D'Aprés Renouvier," Revue de Métaphysique et de Morale XXVI (1919): 
685; Louis Prat, "Les Derniers Entretiens de Charles Renouvier," Revue de Metaphysique et de Morale XII (1904): 170 .

21

Crawford 62 .

22

Crawford 63.

23

Soltau 251, 306-7.

24

Soltau 304, 307, brackets inserted.

25

Soltau 307.

26

Soltau 352-3.

27

William James, notes, The Nation XVI 30 June 1873:

94 .

28

William James, "Bain and Renouvier," The Nation XXII 8 June 1876: 368 .

29

Perry, vol. 1, 664 .

30

William James, Essays in Philosophy, eds.

Frederick H. Burkhardt, Fredson Bowers, Ignas $K$. Skrupskelis, The Works of William James, 9 vols. (Cambridge: Harvard University Press, 1978) vol 5, 360.

31

William James, Collected Essays and Reviews 114;

Wahl 72; Perry, vol. 1, 656 . 
32

Perry, vol. 1, 658; James, Collected Essays and

Reviews 31, 194, 200; James, A Pluralistic Universe 391.

33

Perry, vol. 1, 657; Robert J. O'Connell, William

James on The Courage to Believe (New York: Fordham University Press, 1984) 94.

34

Allen 225.

35

William James, Essays in Pragmatism, ed. Alburey Castell (New York: Hafnes Press, 1948) 37-39.

36

Perry, vol. 1, 659, 669, 689.

37

Allen 202.

38

William James, Some Problems of Philosophy: A

Beqinning of an Introduction to Philosophy (New York: Longmans, Green, and Co., 1911) 165.

39

Bruce Kuklick, The Rise of American Philosophy:

Cambridge, Massachusetts, 1860-1930 (1977 New Haven: Yale Univeristy Press, 1979) 257.

40

McDermott 139, 151.

41

McDermott 141-2.

42

McDermott 151.

McDermott $138,152$. 
44

Perry, vol. 2, 647 .

45

McDermott $v i$.

46

McDermott vi $\mathrm{i}-\mathrm{x}$.

47

McDermott 349.

48

James, Varieties xix.

49

James, Varieties $x \times i$.

50

James, Varieties 520 .

51

James, Varieties 520-27; Boutroux, William

James 87.

52

Perry, vol. 2, 650.

53

Perry, vol. 2, 599.

54

Levi 57-8.

55

Perry, vol. 2, 603, 608 .

56

William James, The Letters of William James, ed.

Henry James, 2 vols. (Boston: The Atlantic Monthly Press, 1920) vol. 2, 198; Perry, vol. 2, 377.

57

Perry, vol. 2, 745-7.

58

Perry, vol. 2, 748-9. 
59

Perry, vol. 2, 385.

60

McDermott 194 .

61

McDermott 214 .

62

Perry, vol. 2, 605-6, 609.

63

Perry, vol. 2, 609-110.

64

Perry, vol. 2, 750.

65

Perry, vol. 2, 394.

66

Perry, vol. II, 619.

67

Perry, vol. II, 656.

68

Kuklick 331 .

69

James, A Pluralistic Universe $212,244,246$.

70

James, A Pluralistic Universe 251-3, 262,

$279,282-86$

71

Perry, vol. 2, 664.

72

Perry, vol. 2, 764.

73

Henri Bergson, An Introduction to Metaphysics,

trans. T.E. Hulme, with an introduction by Thomas A. Goudge 
(1903 Indianapolis: ITT Bobbs-Merrill Educational Publishing, 1985) 37 .

74

Horace Meyer Kallen, William James and Henri

Bergson: A Study in Contrasting Theories of Life (I11 inois:

The University of Chicago Press, 1914) 20.

75

James T. Kloppenberg, Uncertain Victory: Social

Democracy and Progressivism in European and American Thought,

1870-1920 (New York: Oxford University Press, 1986) 40.

76

Perry, vol. 2, 599, 602 .

77

Perry, vol. 2, 634 . 
CHAPTER IV

WILLIAM JAMES, MAURICE BLONDEL AND EMILE BOUTROUX

In the 19th Century, empiricists, absolute idealists and positivists increasingly could find no common ground, other than their belief in objective Eact. Their conception of objectivity resulted in the posing of the question of the relation between science and religion in terms of opting for one or the other. The conception of their incompatibility derived from the assumption that truth was based on fixed, unified external fact, like the laws of nature. The idea that a law was an objective invariable necessity and consequently an eternal truth led to the assumption that ultimate questions, which were the concerns of philosophy, should be answered in terms of fixed laws. The volitional, or passional, which informed religious faith, was individual, personal and irrational, and thus seen as incapable of objective confirmation. A review of the respective positions of the three main views will lead us to the discussion of the relations between James, Blondel and Boutroux.

Metaphysical idealists objectified Kant's conceptual categories and claimed to deduce the unfolding of reality by conceptual categories. Positing an objective Absolute 
Ego that manifested itself in the activity of thought, NeoKantians of the metaphysical variety excluded sensational experience Erom philosophy. On the other hand, empiricists viewed the phenomenal world as the reality with which philosophy was concerned. Their warrant for metaphysical assertions about existence was limited to what could be certified by isolated moments of phenomena. Positivists eliminated supernatural speculation altogether, thereby placing metaphysical or religious considerations outside of the knowing relation. Each way of approaching the world was a closed system exclusive of others. Each was tending towards determinism. Especially vexing was the materialistic attitude developing among empiricists and positivists. James, Blondel and Boutroux tried to meliorate these divisions by defining philosophical inquiry as inclusive of the whole of man's relations in life. They developed their philosophies of action as an alternative view that allowed an approach to phenomena, inclusive of all experience, as it was manifested in action.

James' Pragmatism was a method and a theory of truth that, like Maurice Blondel's philosophy of action, was developed in opposition to closed, deterministic systems. The American pragmatic movement was said to have begun when William James publicly demonstrated its use as a theory of meaning in his lecture "Philosophical Conceptions and 
Practical Results" (1898). In this lecture James explained that his objection to "materialisms grossness" rested on what it left out of account. For James, materialism was:

not a permanent warrant for our more ideal interests, not a fulfiller of our remotest hopes. The notion of God, on the other hand, however inferior it may be in clearness to mathematic notions current in mechanical philosophy, has practical superiority over them, it guaranties an ideal order that shall be permanently preserved. This need of an eternal moral order is one of the deepest needs of our breasts.1

This early statement of James' guided the development of his thought. The similarity in motive and development of thought between James and Maurice Blondel placed them in the identifiable movement of philosophers of action.

Maurice Blondel (1861-1949), a French philosopher, spent his professional career in Southern France. One of the major influences on Blondel was his instructor Emile Boutroux. Boutroux had encouraged Blondel to write a technical presentation of a philosophy of action. Blondel presented his philosophy of action in his 1893 dissertation. However, some philosophers saw Blondel's philosophy as a religious apologetic, which for them, was unsuitable in philosophic discourse. Blondel's thought was dangerously outside what said had referred to as the intertextual references that insures the continuity of particular viewpoints. Because he deviated from the philosophic traditions ensconced in the French educational 
system, Blondel was refused for consideration as a candidate for a chair in philosophy. On Blondel's behalf, Boutroux appealed to his cousin, Raymond Poincaré, the Minister of Education, to intercede for Blondel. By Poincaré's initiative, Blondel was given the Chair of Philosophy at Aix-en-Provence.

The nature of Blondel's thought began from the same point of view affirmed above by James. Blondel's initial question was "how to envisage the philosophical problem in the light of religion" without philosophy being a substitute for religion or philosophy being absorbed into religion. His philosophy of action was developed in response to the division of philosophy into separate schools. Like James, Blondel sought to conciliate between the anti-metaphysical positivism and the limitations of absolute idealism.

Blondel's dissertation Action (1893) carried the general theme that man discovered himself through action that included all of the relations of 1 ife. He saw the "whole man" as a unity "composed of intelligence, feeling and deliberate will." He used the scientific (rational) method of dialectic to demonstrate the dynamic movement in Iife to the idealistic immanentists, and in order to establish a method for a metaphysics of the philosophy of action. 
Blondel began Action (1893) with the question of human destiny in order to examine "the meaning of existence" by a philosophy "open to the transcendent as yet 7

undefined." Like James, Blondel began his work with the religious option. By the dialectical movement of the work, Blondel showed that man could not 1 imit his knowledge to objective science but must have a "science of the 8 cy examining the movement of consciousness, subject." By examining the movement of consciousness, Blondel showed how consciousness "exercises itself as freedom."

Blondel explained his intention in Action (1893):

It focused on the following two problems and with the attitude defined as follows: 1. A study of the relations between thought and action conducted in such a way as to constitute a critique of 1 ife and a science of practice, with the aim of arbitrating the contention between intellectualism and pragmatism [the purely secular variety] through a 'philosophy of action' that includes a 'philosophy OF the idea' instead of excluding it or limiting itself to it. 2. A study of the relations between science and belief and between the most autonomous philosophy and the most positive religion conducted in such a way as to avoid rationalism as well as fideism and with the aim of uncovering through a rational investigation the intrinsic claims of religion to be heard by all minds. 9

By beginning with the religious option, Blondel showed that the will required and directed movement so that a choice for no action was not possible. At the heart of Action (1893) was the "equating the term willed with the principle of the voluntary aspiration itself." Practice did not tolerate any delay and never entailed perfect 
clarity: "I cannot put off acting until all the evidence has appeared. In every act, there is an act of faith." By a phenomenalogy of action that included ideals for an openended future, Blondel showed the incoherence of the positive sciences. For example, Blondel pointed out that even "brute bodies" manifest an "internal dynamism" because, "The living germ effects, with the materials it gathers, a veritable creation, and as long as there is life, there is a phenomenon of surplus production." fact of surplus production validated the existence of plurality in the changes unfolded in life and obviated the idea of fixed, linear development.

Blondel's philosophy of action was an attempt to unite the "philosophy of essence and the philosophy of existence" to overcome the conflict between science and religion. Like James, Blondel considered that the conflicts between schools derived from their "closed systems." By looking to "thought clarified in action and action clarified by reflection," he showed that thought and action were "ultimately one." ${ }^{12}$ Blondel wrote that in Action (1893) he had advocated "moralism," by which he meant to, "preserve the equilibrium of a doctrine which is an integral realism and which does not sacrifice either of the aspects of being, either thought or life." ${ }^{13}$ Pascal was his inspiration for seeking being in man and the 
constitution of a "concrete ontology" because both saw the problem of being as also "the problem of the spirit, of charity, of socialization and personalization simultaneous $1 y . "$

Initially outside of Blondel's own circle, william James was one of a very few who showed any interest in 15

Action (1893). Blondel indicated their points in common in 1902 when Blondel had publicly proposed the term "Pragmatism" for his philosophy of action. However, he rejected the term later because he did not want his philosophy of action to be confused with the brands of pragmatism that excluded a principle of "fixed orientation and progressive adaptation." Although Blondel and James differed in their conclusions about God's role and institutional religion, their basic orientation was one of meliorating the division of the schools by grounding metaphysics in the relation of thought and practice through action, which called for an empiricistic, futuristic, intrinsic philosophy.

Blondel continued his defense of a philosophy of action in a 1906 article, "Le Point de Depart de la recherche philosophique" in the Annales de Philosophie

Chretienne. James read the article and wrote to Blondel "You have stuck a magnificent note in the Annales. I have copied whole pages of your words." In the article, Blondel 
had again addressed the problem of how philosophy could constitute both a "technical discipline" and at the same time be "inserted into the common life of humanity." ${ }^{16}$ To do so, philosophy should start with direct knowledge that served as real "plans" for the totality of life that faced the future and "evoked it," and philosophy must use reflective knowledge, which by "abstraction" was "retrospectively analyzed." James was later to put it this way: "We live prospectively as well as retrospectively." For Blondel, the relation of consciousness and action raised a problem for reflection as a "technical discipline." Resolving the problem by connecting theory and practice in a revolving wheel, allowed philosophy to pose specific problems according to their object. As prospective, philosophy would prepare "directive ideas' Eor life. A phenomenological method would avoid "idealistic or realistic" bias and get at what we actually conceive ourselves as being and thinking; it allowed an "inventory of the given" to ascertain the meaning of dynamic movement inclusive of the mind and nature.

In A Pluralistic Universe (1909), James' quoted Blondel, "Our thoughts determine our acts and our acts redetermine the previous nature of the world." He also quoted Blondel's placement of philosophy as explaining and making the world, "It [philosophy] is of the real in the real." 
In the Preface to pragmatism (1907) James referred the reader to Blondel's article in the Annales. Like Blondel, in Pragmatism, James explained that "philosophy is prospective." After finding what "the world has been and done and yielded," it asked, "what does the world promise." His pragmatic method was a method of "settling metaphysical disputes--Is the world one or many, Eated/Eree, material/spiritual." 20

James explained that pragmatism derived from the same Greek word, "meaning action, Erom which our words practice and practical come." The viewpoint of pragmatism was that the truth of a "state of mind means this function of a leading that is worth while." Truth was a process whereby an idea was made true by events. For James, pragmatism was both a theory of truth and a theory of meaning; those who were pragmatists turned towards "concreteness, adequacy, facts, action and power."

As a method for settling metaphysical disputes, pragmatism found the evidence for God in inner personal 22

experience. The fact that the world was "One" by its conjunctions and "many" by its disjunctions, meant that we could know the variety by developing "distinct programs of scientific work;" that is, by developing a method for every object. The notion of the Absolute would be "replaced by that of the Ultimate" because systems evolved 
from human needs, which changed and developed through time. For James, the notions of the Absolute and the Ultimate were both concerned with maximizing the "unified content of fact" but they were opposite conceptions of time. The first was backwards, the latter forwards.

James had expressed his belief that a technical defense for a philosophy of practice (action) could be made but he had not found the time to present it himself. Blondel's technical defense of a philosophy of action firmly established a philosophic view that explained the relation between theory and practice. It prompted a metaphysics that was consonant with James desire for a philosophic view that began from human experience and was capable of approaching a pluralistic universe that allowed the rational and the empirical to be considered on equal terms.

James worked out his metaphysics during the last ten years of his life, which he presented in Apluralistic Universe. He stated the advantages of his philosophy that accommodated both rationalists and empiricists by quoting Blondel (Blondel's statement is the quote within this quote):

Meanwhile the incompleteness of the pluralistic universe, thus assumed and held to as the most probable hypothesis, is also represented by the pluralistic philosophy as being self-reparative through us, as getting its disconnections remedied in part by our behavior. 'We use what we are and 
have, to know; and what we know, to be and have still more.' Thus do philosophy and reality, theory and action, work in the same circle indefinitely. 24

From Blondel, James had found a way of expressing the contextual place of philosophic activity. Rather than philosophy conceived as reified expressions of fixed truths, James used Blondel's conception of philosophy as an activity in the midst of human experience. By this, they both were able to Eind a place for philosophy that did not separate it from the whole of human needs. Blondel's philosophy of action had continued the philosophic position that Emile Boutroux carried forward in his works and lectures to his students. We can look to Boutroux for the fundamental points that unite these philosophers of action and comprise those elements that make them a part of an identifiable movement.

\section{James and Emile Boutroux}

"Brute datum indistinguishable from pure accident. We have to try to make it seem less of an accident, less of an arbitrary fact." - -Will iam James 25

Perry asserted that a "really growing world" was "the theme" of the latter part of Some Problems of Philosophy, and that this theme bound James to Bergson.

The problem of reconciling confidence in science with the assertion of chance, as we have seen, was expressed, according to James, in a more satisfactory way by Bergson's use of continuity. 
To more clearly understand the way Bergson, James and Blondel came to express so many similarities in their views and the fact that these similarities are evidence of their participation in a particular movement of the 19th Century, we can look to the philosophy of Emile Boutroux who was pa crucial in influencing the philosophic vision of Bergson and Blondel who were his students.

The separation of mind and body, the tension between subjectivity and objectivity rooted in conceptions about science and religion was so profound that these philosophers of action attempted to anninilate these exclusive oppositions. As noted, Bergson, James and Blondel each considered the oppositions of prevailing philosophic views to have reached a crisis point in the exercise of intellectual freedom and in the construction of a reasonable conception of 1 ife. Calm resides at the center of a storm. Emile Boutroux (1845-1921) was the calm at the center.

Boutroux's education followed the course of the elite in the French educational system. His professional career was centered in Paris. He was Professor of History and Modern Philosophy at the Sorbonne, and a Director of the Foudation Thiers, from which he influencd an elite of young men. He was elected a member of the Institute in 1898 and elected a member of the French Academy in 1912. The year 
1895 saw the republication of Boutroux's 1874 thesis, The Contingency of the Laws of Nature due, in part, to the influence of his ideas on his students, Henri Bergson and Maurice Blondel. Additionally, Boutroux's critique of science was recognized as influencing Hannequin, Payot, Milhaud, Duhem and Henri Poincare.

In a 1910 article in The Nation, "A Great French Philosopher At Harvard," William James gave notice to "converts" to pragmatism, Bergsonism, "the real empiricism, the real evolutionism, the real pluralism," that it was Emile Boutroux who had "set the ball rolling" and was the earliest (after Renouvier) as he is now its latest, 28

prophet." James noted that that which these views stood for could be found in Boutroux's 1874 thesis, The Contingency of the Laws of Nature, and that "the most important Eeatures of "pragmatism" and "Bergsonism" Eound clear expression in that early work." James' explication of his assertion is the best summation of the thesis of this paper.

According to James, "M. Boutroux is, by virtue of priority, the leader de jure of the reaction against the abstract, and in favor of the concrete point of view in philosophy." James defined the "abstract" that Boutroux reacted against as the common sense notion of the "scholastic" point of view, which meant "the pretension to 
conceive things so vigorously that your definitions shall contain all that need be known about their objects." 29 The dogmatic conclusions of rationalists was the position that James took his stand against in Introduction I of his unwritten book to be entitled "The Many and the one," which was to be a "conjunction of ideas, empiricism and spiritualism." Perry recounted that James had begun with a testimony to the practical "serviceability" of the categories of body, soul and causality, but had "suspended" the project at the point of taking up the divided philosophical positions. In these papers of 1903-04, James was with Boutroux against absolute systems. However, James had not been ready to explain his metaphysical thought.

James' notes on metaphysical problems, gathered from 1903 onward, contain his intention to "Begin construction by the question of Realism vs. Idealism" in order to "Eoreshadow" his "collective pluralism, purposive impulse" philosophy. Perry recorded that for James, the "value of idealism" was in its ability to disprove the "materialistic view of physical nature." In this, James felt reenforced by Poincare's and Le Roy's conception of physical laws and concepts being conventions, chosen for their utility. ${ }^{31}$ As noted, Poincare was heavily influenced by his association with Boutroux and his thought. For Boutroux science was reduction, and mathematics was its form "par excellence." 
For science to explain the universe, would be to make it "one and eternal" in a perfect formula "regarded as the equivalent of the entire diversity and movement of 32 things."

Boutroux's view of science can be seen in Poincare's description of the functional role of ideals:

The scientist's love of truth is not the love of certitude... The faith of the scientist would rather resemble the faith of the heretic...it makes us catch a glimpse of [entrevoir] an ideal of which we can have only a vague notion, and it gives us the confidence that, without ever permitting us to attain it, our efforts for approaching it will not be without fruit. 33

James had registered his disapproval of a rigid conception of science, and of men of science speculating about ultimate problems as early as 1874 in "The Mood of science and the Mood of Faith." He found a thorough defense of his position in Boutroux who came out against the followers of Comtism, or scientism, "who imagined that the frame of things was eternally and literally mechanical, and that truth was reached by abstracting from it everything connected with personality." Accounting Eor life by a law, such as the conservation of energy could never attain the ultimate reason of things. Boutroux found in the evidence of evolution that "force making Eor change" is "at the root of force making for conservation."

James identified Boutroux's central thesis inclusive of what Boutroux was against. He was opposed to reality as 
"abstracted, simplified, reduced, inalterable and selfidentical." For James, Boutroux "rescued" reason from "tracing identities," which classical rationalism imposed upon itself because, as James saw it, they considered even an elementary novelty equivalent to admitting "Absolute Chance at the heart of things." 37 For Boutroux, "identity" was only found in words. In nature, no two individuals were identical. "Nature never gives us anything but resemblances...similarly, positive science does not require the possibility of reducing all notions to unity."

James applauded Boutroux's preference for reason as the "faculty of judgment in its widest sense," which included sentiments, willingnesses, concepts and premises. Boutroux examined the laws of logic, mathematics, physics, chemistry, biology, psychology and sociology, and concluded that "everything changes, except the law of change." Boutroux advocated ridding ourselves from "all rational systematisation," the single-fact, permanently-explained universe, and substituting "the simple design of a 40 genealogical tree." with the logic of identity, a strict law of cause and effect, invariably "escapes" us due to an element of contingency in things. 41

Boutroux set forth the idea of immediate experience as "less rigorous" than the systematisation of thought. If we were to eliminate "all intellectual activity, all 
participation of the understanding," it would be an "inconceivable process." For experimental knowledge, we require an object and extract "the data of the senses or of 42 the empirical consciousness." This is similar to James" later notion of pure experience, which applied radical empiricism to the theory of knowledge and found immediate experience to be neutral, with the subject/object distinctions occurring according to interest.

James had been concerned to lessen the effect of conceiving the "tychism" he early adopted as an "arbitrary fact." He credited Boutroux with avoiding the problems encumbent upon "chance" by Boutroux's demonstration of "contingency." Human life was characterized as spontaneous, wherein our consciousness expects "many" future possibilities and the present "contains always enough causality for either. Our living reason makes its choice. Ever something new, but never anything entirely new." In Boutroux's philosophy of contingency, there was a stable pluralism that did not violate the intellectual demands of reason. Boutroux's work established an important shift in thought. The human mind and the environment interact; human reason creatively and continuously extricated entities to be understood; "theories result from psychological variations." 
James, Boutroux's originality was in "Interpreting the whole of nature" from "our own personal experience."

In 1909 James wrote to Theodore Flournoy, in reference to Boutroux, "the times being now fully ready for that way of thinking, as they were not when he published his first book." Perry put forth the general thesis of this paper when referring to James' account of Boutroux in The Nation: "In expounding Boutroux's philosophy it is evident that he is at the same time expounding his own." As we noted, James said exactly that in the article. A brief survey of Boutroux's work will indicate the importance of the connections between James, Renouvier, Bergson, and Blondel.

Rothwell proclaimed the highest honor on Boutroux for having humanized the philosophy and ethics of his day. James held that Boutroux explained men of science, philosophy and religion to each other. The battle for authority between the three was the crisis of the 19th 47

Century.

Boutroux addressed each of these areas in his 1874 thesis. Boutroux justified the following assertions, in addition to those noted above. Philosophy should be grounded on the sciences and should put itself in direct touch with the realities of nature and life. Idealist, materialist, dualist or parrellelist types of philosophy force us to regard laws of nature as a chain of necessity. 
This made liberty an illusion and should be replaced by a philosophy that was living and molded on reality. Boutroux's intention was "to restore to man his will and action," because the processes of nature revealed its transcendent character. Nature was living, and developed; its laws were contingent and man could rise towards a higher life. 48

The reality of contingency meant that any particular standpoint of understanding was not the ultimate standpoint 49

of the knowledge of things.

Being occurred as a result of the act of choosing between contraries. The act could only choose between things derived from experience, therefore, being originated only from experience. "The law of causality is the synthesis of two mutually irreducible elements, change and identity." science saved man from caprice, which was good, but science must not hold "exclusive sway" and reduce belief to fatality.

James specified Boutroux's view of reality, its consequences and its source:

It is the element we wholly live in...it is the superabounding, growing, ever-varying and noveltyproducing. Its real shape is biography and history....the whole undivided jungle, with our personal life and all, is the reality immediately given...and more real than...any conceptual substitutes. The great originality of M. Boutroux thoughout all these years has been his $\mathrm{firm}$ grasp of the principle of interpreting the whole of nature in the light of that part of it with which we are most fully acquainted, namely, our own personal experience. 51 
In Contingency Boutroux introduced elements seen in Bergson, James and Blondel. Boutroux looked at matter, things that could be counted reduced to extension and motion, "for motion implies duration and produces diversity, whence results number." On the other hand, notions were discontinuous.

Time is a continuous duration and motion a continuous passing. This idea of continuity, restored to the concept of extension, time, and motion brushes aside the sophisms into which one is led when attributing to these concepts a purely logical signification. The mathematical properties... involve a new element, heterogeneous and irreducible: continuity. 52

James, Bergson and Blondel develop their philosophies with this principle.

In view of heterogeneous continuity, the idea of "facts as necessary" should not be imposed on all of the sciences and morality. Sounding very much like James' later development of his theory of truth and pluralism, Boutroux posited his doctrine of contingency as his thesis. The rejection of contingency "would be misjudging the law by which, when there is no reason why one of two opposites should come about rather then the other, nothing results." 53

Boutroux followed the tradition in which Renouvier participated and extended. In Contingency Boutroux carried the idea of freedom into a newly developed form. If things were to be "modified contingently," man must act. 
Freedom was the basis of the "outer sign" of contingency; freedom was "creative power, prior to action." 54 All of these philosophers of action discussed here have in common Boutroux's statement of 1874 :

The mode of knowedge should be suited to the object to be known;...to know the relation between the sensible and the suprasensible, there is needed a faculty, for which both fact and idea, sign and thing signified, cease to be radically distinct. Action...reveals to the intellect the reality of power or of cause, as the creative and spontaneious principle which exists before, during, and after its manifestation. 55

Discussing the metaphysical application of Kant's thought for Boutroux's contemporary world, he suggested that instead of idealism and empiricism (the real and the ideal) being on guard against each other, by including each other, "politics ceases to be incompatible with morals." As for Kant, so for Boutroux: For man, "freedom to think and make known his thoughts is the condition of the progress of enlightenment." 56 william James, Charles Renouvier, Henri Bergon, Maurice Blondel and Emile Boutroux, as philosophers of action, each jought melioration by their intrinsic, empiricist, spiritualistic, pluralistic, futuristic philosophies in many respects like Kant and in the manner of Pascal's integralism.

Boutroux captured the essence of these philosophers of action:

Philosophy of knowledge, for which the sciences furnish the material, is not the whole of 
philosophy. Just as real and legitimate is the philosophy of action, life properly so-called, the social and individual destinies of humanity.57 
Notes

1

McDermott 345 .

2

Maurice Blondel, Letter on Apologetics and

History and Doqma, presented by Alexander Dru and

Il1tyd Trethowan (London: Harvill Press, 1964) 43.

3

Blondel, Letter 53-4.

4

Blonde1, Letter 55.

5

Maurice Blondel, Action (1893)--Essay on a

Critique of Life and a Science of Practice, trans. Oliva Blanchette (1950 Indiana: University of Notre Dame Press, $1984) 442$

6

Blondel, Letter 87.

7

Blondel, Action 1,3; Blondel Letter 54 .

8

Blondel, Action $\times x i$.

9

Blondel, Action $x \times i i$, brackets inserted.

10

Blondel, Action 406 .

11

Blondel, Action 85.

12

Blondel, Letter 55.

13

Blondel, Letter 64 . 
14

Blondel, Letter 73.

15

Blondel, Letter 56.

16

Frederick Scott, J.D., "William James and Maurice

Blondel," The New Scholasticism XXXII 1972: 33.

17

William James, Essays In Radical Empiricism

(1912 Massachusetts: Peter Smith, 1967) 122.

18

Blondel, Action $427 ;$ Scott 34 .

19

William James, A Pluralistic Universe 318.

20 William James, Praqmatism 25, 49.

21

James, Pragmat ism 28, 33, 94.

22

James, Praqmatism 52.

23

James, Pragmatism 69, 72 .

24

James, A Pluralistic Universe 329-30.

25

William James, Essays in Philosophy, eds.

Frederick H. Burkhardt, Fredson Bowers, Ignas K. Skrupskelis, vol. 5 The Works of William James 9 vols. (Cambridge: Harvard University Press, 1978) 360.

26

Perry, vol. 2, 664 . 
J. Alexander Gunn, "The Philosophy of Emile Boutroux," The Monist XXXII.2-Apr. 1922: 170 .

28

William James, "A Great French Philosopher At Harvard," The Nation XC 31 March, 1910: 314.

29

Emile Boutroux, "Hasard ou Liberte?", Revue de Metaphysique et de Morale XVIII (1910): 140 .

30

Perry, vol. 2, 380-81.

31

Perry, vol. 2, 381 .

32

Emile Boutroux, Natural Law in Science and

Philosophy, trans. Fred Rothwell (London: David Nutt, 1914) 6.

33

Mary Jo Nye, "The Boutroux Circle And Poincaré's Conventionalism," Journal of the History of Ideas XL-1 January-March 1979: 118 .

34

William James, "The Mood of Science and the Mood of Faith," 437 .

35

James, "A Great French Philosopher" 313.

36

Emile Boutroux, The Contingency of The Laws of

Nature, trans. fred Rothwell (London: The open Court Publishing Company, 1916) 105. 
37

James, "A Great French Philosopher" 314.

38

Boutroux, Contingency 43.

39

Boutroux, Contingency $41,46,59,73,133$;

Natural Law 15,65 .

40

Boutroux, Contingency 47 .

41

Gunn 171.

42

Boutroux, Contingency 54.

43

James, "A Great French Philosopher" 313.

44

James, "A Great French Philosopher" 314.

45

Perry, vol. 2, 567.

46

Fred Rothwell, "Emile Boutroux," The Monist vo1. XXXII No. 2-Apr. 1922: 162.

47

James, "A Great French Philosopher" 314; Gunn 197.

48

Boutroux, Contingency vii.

49

Boutroux, Contingency 7 .

50

Boutroux, Contingency 19, 21, 23.

51

James, "A Great French Philosopher" 314.

52

Boutroux, Contingency 52 . 
53

Boutroux, Contingency 64 .

54

Boutroux, Contingency 173 .

55

Boutroux, Contingency 178 .

56

Emile Boutroux, Historical Studies in Philosophy

trans. Fred Rothwell (1912 New York: Kennikat Press, 1970: 314 .

57

scott 32 . 
CHAPTER $V$

CONCLUSION

An enduring fact in the history of philosophy has been man's attempt to explain his world and his place in it. Philosophy is, then, a vision of the world constructed by philosophers who seek to place the multiplicity of facts in the experiences of their age in an order that supplies a meaningful interpretation. A study of the earliest recorded philosophies to those of present day philosophers show that they have begun their inquiries by considering the philosophic expression of their predecessors in the light of their own contemporary experiences. In short, a major function of philosophy has been its analysis of contemporary problems of society in a particular historical period in order to supply an understanding that will lead to a more harmonious society where attitudes are consistent with contemporary facts and serve as a guide in the proper conduct of human affairs.

An example of the contextual influences that inform the development of philosophies can be seen in classical Greek culture where the need for moral guides inspired Socrates to cross examine the prevailing trends of thought 
in their relation to the political organization of the Greek polis. The classical Greek mentality was shaped and focused on man's contributing role in his city state. The ritualistic world of an oral culture had gradually given way to new socio-economic factors that influenced the development of a democratic political structure that reguired individual initiative and a moral philosophy enabling the discernment of conduct condusive for the "good life."

In each historical period the history of ideas shows that the prevailing philosophy was a product of external factors, individual need and intertextual exchange all interrelated in the maintenance of a particular philosophy. When a philosophy no longer explained the whole of realities in a culture, it was superceded by another. Ideas are facts that are affected by, and in turn affect, the political attitudes and activities of society. It is by facing similar facts that philosophers of an age address similar problems in order to reconcile their society with current realities.

In this thesis, we have explored the social challenges of the United states and France in the 19 th Century. Both countries shared a number of basic areas of social, political and intellectual instability. These areas produced a discordance in the social fabric and thus 
were an invitation to intellectuals of both countries to grapple with the causes and solutions pertinent for their age.

In the United States, post-Civil war reconstruction included the national political need to provide a common focus for Americans in order to raise political consciousness above the level of regional divisions. Along with the domestic political needs of the United states, there was the desire to become a political power of importance within the larger international context. The development of science as a means to promote American interests was an important part of the overall political agenda. We have focused on the political ramifications within institutions of higher education as each strove to establish themselves as preeminent academic institutions within the international community. The second half of the 19 th Century saw the organization of graduate schools and the competition to attract and produce internationally recognized scholars. The contributions of science to the welfare and prestige legitimized the placement of scientific investigations as a primary goal. The problems for the pursuit of overall knowledge was the incomplete understanding of the nature of scientific investigation.

The scope and limitations of science concerned intellectuals like James, who believed in the efficacy of 
scientific method but found its intrusion into the humanities caused a myopic vision that threatened the exercise of intellectual freedom. The debates over Darwin exemplify the problems that occurred when facts about the physical nature of the world and man, obtained by scientific observation, were employed in theoretical explanations of the affective, spiritual and moral 1 ife of man.

In France, Renouvier, Bergson, Blondel and Boutroux faced an acute situation as the divided groups in national politics adopted ideological systems as political tools. Unlike the United states, in France the new democratic political system was challenged by archaic monarchical political convictions. Comte's positive science was employed as a political tool to secularize French society. The promotion of positivism was a means by which republicans could revive the emphasis on reason associated with the 1789 French Revolution.

There was, then, a socio-political basis for using positivism to justify the exclusion of the Catholic Church from interference in the Republican reconstruction of society. The state control of education brought the political battles into the universities, thereby, threatening intellectual freedom at its center of activity. Scholars were intimately involved in national and 
institutional politics that proved divisive for the intellectual community. Men of science, philosophy and theology were drawn into political activity as seen in the movement of the Action Française, the Catholic Modernists, the Neo-Thomists and the Conventionalism of Henri Poincaré.

Given the similar societal problems in France and the United states, it is not by chance that James, Renouvier, Bergson, Blondel and Boutroux should have developed a symbiotic relationship in addressing common problems. These five philosophers participated in a reasoned development of a philosophic approach based on action. This approach sought to understand and explain their contemporary 19 th Century society that struggled to overcome previous authoritative systems and can be seen as an identifiable movement.

This thesis has argued that william James' philosophy was to a great extent derived from his interaction with these French philosophers and that in order to understand James' philosophy, he must be placed within the context of these relations. My primary concern has been the philosophy of William James. However, it is important to mention some of the references by these French philosophers to James. Renouvier reprinted at least nine of James' essays in the French journal La Critique Philosophique. 
Bergson wrote the Introduction to the French translation of Pragmatism and the Introduction to the French translation 1

of James' letters. Boutroux included a chapter on James

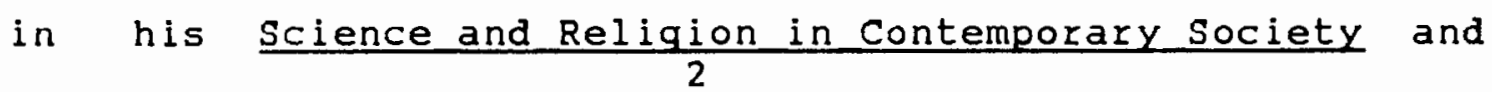
wrote a biography of James.

To more fully understand James' philosophy this thesis has presented the ideas derived from these French philosophers. As noted by his own remarks, James' direct relationship with each is indisputable. The elements of his philosophy derived from his exchange with them should be summarized. By his adoption of Renouvier's conception of free will, James broke with monistic philosophies that presented closed systems of thought. James placed an act of self affirmation as the heart of any philosophic system, which put him in the camp of open, pluralistic philosophies that included choice.

James adopted Renouvier's phenomenalism, which included the relations between things in a given context, which James called the "new empiricism." For James, ideas, will, and action were instrumental in the construction of any philosophy, which meant that there was a subjective element. James' pluralism was based on Renouvier's view that "the whole is an expression of the interaction of originally independent forces," which accounts for James' preference for the priority of part to 
whole. By starting from Renouvier's voluntary belief, James proposed that the consequences of action on belief would either verify or invalidate the truth of an original hypothesis. The notion of free will carried the seeds of James subsequent development of his pragmatism. Rather than giving primacy to conception or perception, James viewed both as interrelated activity. By these assertions, James employed a Neo-Kantian emphasis on the practical rule that included empiricism and ideals for future action in his conception of moral philosophy.

The problem of dualism, which separated the subject and object was overcome by his exchange of ideas with Henri Bergson. The logic of identity derived from mathematical equations which held that the idea and the thing must be identical equivalencies. The problem that arose from the application of logic to experience resided in the fact that two people could know (have in mind) the same object. Did the object then have two realities?

Bergson held that the logic of identity was a static picture of experience that only occurred in discourse. In actuality, all experiences came undivided and flowed in a continuous fashion into one another. There was no separation between the subject and object until man's interest determined which was to be attended to. pure experience was given and the pluralism of choices meant 
that life was a continuous process of creative becoming. By this, James was able to solve the problem of coconsciousness and develop a metaphysics consonant with experiential life. Knowledge was not simply thought relations, but was a function of cognition which included "thinking-feeling-consciousness" in a process of interaction. His Radical Empiricism meant that reality was a pluralism wherein series of phenomena could be interrupted and a new series begun. This last point had been present in James' thought due to the influence of Renouvier. By his relation with Bergson, James was finally able to construct its metaphysical explanation.

The continuous creative movement of 1 ife meant that each moment was self-transcendent. Consequently, novelty was possible without abandoning the concrete facts of lawin-change. Understanding the way concepts cut up the movement of life allowed the placement of conceptual constructions in their as guides for future action. A metaphysics of action could go beyond conceptual science. The choice between absolute idealism and empiricism was no longer a valid question from the viewpoint of the interrelations of all action, which included the activities of thinking and feeling in a doctrine of compenetration.

Blondel's technical presentation of a philosophy of action showed how consciousness exercises itself in 
freedom. He equated the will with voluntary aspiration and showed that in practice empiricism and idealism were united. In reality, thought and life were not separable. By Blondel's demonstration of philosophy as starting with direct knowledge and constructing plans that evoked the future that was conceived, he showed that a practical philosophy recognized retrospective conceptualization and prospective plans. James referred the readers of pragmatism to Blondel's work for a further understanding of philosophy as the real within the real; philosophy was not separate from life, it was a part of life taken in its totality. Quoting Blondel in A Pluralistic Universe, James maintained that theory and action work in the same circle indefinitely. From this, James held that the pluralistic philosophy saw the universe as self-reparative.

Following the philosophic tradition of which Renouvier was a part, in 1874 Boutroux put forward the conceptions that were in part to appear in the work of these philosophers of action. Against exclusive abstraction and the reductionism of comtism, or scientism, that viewed reality in mechanistic terms, Boutroux rescued reason from tracing identities. Boutroux's conception of contingency explained novelty without requiring that absolute chaos be admitted. This problem had bothered James since the $1870^{\prime}$ 's when he had adopted free will and 
tychism (chance). With Boutroux, James could abandon "chance" in favor of a clearer conception of novelty. There could be positive science without reducing all notions to unity. For James, Boutroux was the leader in interpreting the whole of nature from man's personal experience. Boutroux's conception of the law of causality as the synthesis of "two irreducible elements, change and identity," allowed for science and belief. He demonstrated that science must not hold "exclusive sway." James' advocacy of both science and religion, each on their own terms, found its expression in Boutroux's thought.

Each of the philosophers of action sought to meliorate the opposing positions of philosophical schools that proposed an anti-metaphysical positivism or an absolute idealism, by placing both within experience understood by the nature of action. As philosophers of action, they each contributed to the humanization of the philosophy and ethics of their day. By making philosophy a life and not a view, "a practice and not a theory of practice", they "renewed the meaning of philosophic activity itself." A philosophy of action, as a moral philosophy, advocates the moral education of the individual in his inextricable relations with the collective. Intellectual freedom required the recognition of the multiplicity of experience and devising a method particular 
to the object of knowledge, rather than imposing one method on all inquiry. By abandoning the exclusive view of scientism in philosophy, and proceeding from the viewpoint of action, the world of knowledge would be open and growing.

In Some Problems of Philosophy, James reiterated the points this thesis has stressed as providing a more complete understanding of his philosophy. His pluralism replaced the conception of a universe with one of a "multiverse." Pluralism meant free will. The ontological problem, "or question of how there comes to be anything at all" was really a question of gradual growth. "The conditions of its appearance are uncertain, unforeseeable, when future, and when past, elusive." ${ }^{8}$ There would be novelty, which concepts could not apprehend in advance; however, concepts were effective in science and as ideal constructions of future human experience.

The advantage of pluralism was that it could accommodate monistic views but monism could not accommodate pluralistic views. Pluralism was melioristic by not excluding a variety of views. With pluralism, the world "may be saved on condition that its parts shall do their best." Pluralism was, therefore, more moral. Pluralism did not reject science nor did it reject life. James' melioristic universe was "conceived after a social analogy, 
as a pluralism of independent powers. It will succeed just in proportion as more of these work for its success." ${ }^{9}$ Its character was hypothetical and men were the creators of the worlds conclusion by their action on belief prior to certitude.

James summarized his vision of reality:

reality is flowing,--truth is an aid to action, a guiding thread by which man finds his way and keeps his footing in the mist of perceptual novelty. While for other philosophies truth is a 'discovery', Eor pragmatism it is an 'invention'.10

For James, truth was a function of reality. His cooperative universe held that it was only by man's "precursive" trust that the making of a perfected world 11 could ever come into being.

His whole philosophy follows Pascal's expression of "Two errors: 1. to take everything literally, 2. to take everything spiritually."

\section{2}

By looking at the texts of this period, we can see the contextual nature of knowledge. The society and the philosophy of these five philosophers of action were both pluralistic. By saying that all of our theories are instrumental, James did not mean to say that theories are true because they are useful; rather, James meant that a theory is sustained according to its correspondence with Iife as it is experienced. The degree to which it does not conform is the degree to which it is a fiction. 
Notes

1

Perry, vol. 2, 634-6.

2

Boutroux, Science and Reliqion chapter IV.

3

Perry, vol. 1, 664 .

4

James, A Pluralistic Universe 244, 246, 251, 253,262 .

5

Perry, vol. 2, 664; James, A Pluralistic Universe $279,282-86$.

6

James, A Pluralistic Universe 329-30.

7

Farber 8 .

8

James, Some Problems of Philosophy 45 .

9

James, Some Problems of Philosophy 115, 142, 221,

$299-30$.

10

Perry, vol. 2, 635.

11

James, Some Problems of Philosophy 23.

12

Blaise Pascal, Pensees, trans. A.J. Krailsheiner

(1968 New York: Penguin Books Ltd., 1981) 104. 


\section{A SELECTED BIBLIOGRAPHY}

Allen, Gay Wilson. William James. New York: The Viking Press, 1967.

Anderson, R.D. Education in France 1848-1870. Oxford: Clarendon Press, 1975.

Barzun, Jacques. A Stroll With William James. 1983. Chicago: The University of Chicago Press, 1984.

Baum, Maurice. "The Attitude of william James Toward Science." The Monist XLII.4-Oct. 1932: 585-604.

Bergson, Henri. An Introduction to Metaphysics. 1903. Trans. T.E. Hulme, with an introduction by Thomas A. Goudge. Indianapolis: ITT Bobbs-Merrill Educational Publishing, 1985.

--- Matter and Memory. Trans. Nancy Margaret Paul and $w$. Scott Palmer. London: George Allen \& Unwin Ltd, 1911.

---. Creative Evolution. 1911. Trans. Arthur Mitchel1. New York: Henry Holt and Company, 1913.

--. The Two Sources of Morality and Religion. Trans. R. Ashley Audra, Cloudesley Brereton with W. Horsfall Carter. New York: Doubleday \& Company, Inc., 1935.

---. Selections From Bergson. Edited with an introduction by Harold A. Larrabee. New York: Appleton-CenturyCrofts, Inc., 1949.

Berthelot, Rene. Un Romantisme Utilitaire Etude sur Le Mouvement Pragmatiste. Paris: Librairie Felix Alcan, 1922 .

Blondel, Maurice. Action (1893)--Essay on a Critique of Life and a Science of Practice. 1950. Trans. Oliva Blanchette. Indiana: University of Notre Dame Press, 1984 .

---. Letter on Apologetics and History and Dogma. Presented by Alexander Dru and Illtyd Trethowan. London: Harvill Press, 1964. 
--. Carnets Intimes. Tome 2. Paris: Les Editions Du Cerf, 1966 .

--. Dialoques avec les philosophes. Intro. Henri Gouhier. Paris: Editions Montaigne, 1967.

Blood and Gay, eds. La Vie Catholique dans la France contemporaine. Paris: Comte Catholique De Propagande Française A L'Etranger, 1918.

Bouillard, Henri. Blondel and Christianity. 1961. Trans. James $M$. Somerville. Washington/Cleveland: Corpus Publications, 1969 .

Boutroux, Emile. The Contingency of The Laws of Nature. 1874. Trans. Fred Rothwell. London: The Open Court Publishing Company, 1916.

--- "La Philosophie en France depuis 1867." Revue de Métaphysique et de Morale XVI (1903): 684-716.

--. "La Conscience Individuelle et la Loi." Revue de Métaphysique et de Morale XIV (1906): 1-16.

---. "Hasard ou Liberte?" Revue de Métaphysique et de Morale XVIII (1910): $137-146$.

Science \& Reliqion In Contemporary Philosophy. 1909. Trans. Jonathan Nield. New York: Kennikat Press, 1970.

--- "Du Rapport de la philosophie aux sciences." Revue de Métaphysique et de Morale XIX (1911): 417-435.

---. Historical Studies in Philosophy. 1912. Trans. Fred Rothwell. New York: Kennikat Press, 1970.

-.- William James. Trans. Archibald and Barbara Henderson. New York: Longmans, Green, and Co., 1912 .

--- Natural Law in Science and Philosophy. Trans. Fred Rothwel1. London: David Nutt, 1914.

---. "Jules Lachelier." Revue de Métaphysique et de Morale XXVI I I (1921): 1-14.

Brehier, Emile. The History of Philosophy: Contemporary Philosophy--Since 1850. vol. VII. 1932. Trans. Wade Baskin. 1969. Chicago: The University of Chicago Press, 1973. 
Caponigri, A. Robert. Philosophy From the Age of positivism to the Age of Analysis. Indiana: University of Notre Dame Press, 1971.

Copleston, Frederick, S.J. A History of Philosophy. vols. VII, 1965, VIII, 1967, IX 1977. Book Three. New York: Image Books, 1985.

Crawford, Lucy Shepard. The Philosophy of Emile Boutroux: As Representative of French Idealism in the Nineteenth Century. Diss. Cornell U., 1924. Virginia: Indiana Press, 1924. 158644 .

Dansette, Adrien. Religious History of Modern France. vol. I I. New York: Herder and Herder, 1961.

Dooley, Patrick Kiaran. Pragmatismas humanism--The philosophy of William James. 1974. Chicago: NelsonHa11, 1978 .

Duhem, Pierre. To Save the Phenomena. 1969 Trans. Edmund Dolan and Chaninah Maschler. Chicago: Midway Reprint, 1985.

Dulles, Avery. A History of Apologetics. New York: Corpus, 1971.

Eastwood, Dorothy Margaret. The Revival of Pascal: A study of His Relation To Modern French Thought. Oxford: The Clarendon Press, 1936.

Eros, John. "The Positivist Generation of French Republicanism." The Sociological Review 3.2 Dec. 1955: 255-277.

Farber, Marvin, ed. Philosophic Thought in France and The United States. 1950. Albany: State University of New York Press, 1968 .

Feinstein, Howard M. Becoming William James. New York: Cornell University Press, 1984.

Flournoy, Th. The Philosophy of William James. Trans. Edwin B. Holt and William James, Jr. London: Constable \& Company Ltd., 1917.

Foucault, Michel. Madness and Civilization: A History of Insanity in the Age of Reason. New York: Random House, Inc., 1965. 
Glick, Thomas F., et al., eds. The Comparative Reception of Darwinism. Austin: University of Texas Press, 1974 .

Grogin, Robert c. "Bergson and the French Catholic Revival: 1900-1914." Thought 49.194 sept. 1974: 311322 .

---. "The French Academy Elections of 1914 and the French Right." The Humanities Association Review 29.1 Winter $1978: 61-72$.

Gunn, J. Alexander. "The Philosophy of Emile Boutroux." The Monist XXXII.2-Apr. 1922: 165-179.

Haeckel, Ernst. "Our Monism." The Monist II.4-July 1892: $481-486$.

Haight, Roger D. "The Unfolding of Modernism in France: Blondel, Laberthonniere, Le Roy." Theological Studies 35.4 Dec. 1974: 632-666.

Hamelin, o. "La Volonte', la Liberté, et la Certitudé d'aprés Renouvier." Revue de la Métaphysique et de la Morale XXVI (1919): 685t, XXVII (1920): 666-681.

Hanna, Thomas, ed. The Bergsonian Heritage. New York: Columbia University Press, 1962.

Hardwick, Elizabeth, ed. The Selected Letters of William James. 1960. Boston: Nonpareil Books, David R. Godine Publisher, 1980.

James, William. "Taine's 'On Intelligence'." The Nation XV 29 August 1872: 139-141.

--. "Notes." The Nation XVI 30 June 1873: 94.

-.-. "The Mood of Science and the Mood of Faith." The Nation XIX 31 December 1874: 437.

--. "Bain And Renouvier." The Nation XXII 8 June 1876: 367-369.

---. "The Teaching of Philosophy In Our Colleges." The Nation XXIII 21 September 1876: 177-179.

---. The Variety of Religious Experience: A study in Human Nature. Ed. Martin E. Marty. 1902. New York: Penguin Books, 1982 . 
--. Pragmatism. 1907. Ed. Bruce Kuk1ick. 1981. Cambridge: Hackett Publishing Company, 1982.

--. A Pluralistic Universe. 1909. Massachusetts: Peter Smith, 1967.

---. "A Great French Philosopher At Harvard." The Nation XC 31 March, 1910: 312-314.

Some Problems of Philosophy: A Beginning of an Introduction to Philosophy. New York: Longmans, Green, and Co., 1911.

Essays In Radical Empiricism. 1912. Massachusetts: Beter Smith, 1967.

--. Memories and studies. New York: Longmans, Green, and Co., 1912 .

-.- Collected Essays and Reviews. New York: Longmans, Green and Co., 1920 .

The Letters of William James. Ed. Henry James. vo1 2. Boston: The Atlantic Monthly Press, 1920.

-.- Essays in Pragmatism. Ed. Alburey Castell. New York: Hafner Press, 1948 .

--. Essays in Philosophy. Eds. Frederick H. Burkhardt, Fredson Bowers, Ignas K. Skrupskelis. vol. 5. The Works of William James 9 vols. Cambridge: Harvard University Press, 1978 .

Kallen, Horace Meyer. William James and Henri Bergson: A study in Contrasting Theories of Life. Illinois: The University of Chicago Press, 1914.

Kerlin, Michael J. "Blondel and Von Hugel: The Debate About History and Dogma." The American Benedictine Review 28.2 June 1977: 210-225.

Kloppenberg, James T. Uncertain Victory: Social Democracy and Progressivism in European and American Thought, 1870-1920. New York: Oxford University Press, 1986.

Kolakowski, Leszek. Bergson. Oxford: Oxford University Press, 1985. 
Kuklick, Bruce. The Rise of American Philosophy: Cambridge, Massachusetts, 1860-1930. 1977. New Haven: Yale University Press, 1979 .

LaCroix, Jean. Maurice Blondel--An Introduction to the Man and His Philosophy. 1963. Trans. John C. Guinness. New York: Sheed and Ward, 1968.

L.-Fonsegrive, George. Le Catholicisme et La Vie De L'Esprit. Paris: Librairie Victor Lecoffre, 1906 .

Le Roy, Edouard. The New Philosophy of Henri Bergson. Trans. Vincent Benson. New York: Henry Holt and Company, 1913.

Levi, Albert William. Philosophy and the Modern World. 1959. Bloomington: Indiana University Press, 1970.

McDermott, John J., ed. The Writings of William James: A Comprehensive Edition. By William James. 1967. New York: The Modern Library, 1968.

Maritain, Jacques. Reflexions sur L'Intelligence et sur sa Vie Propre. Paris: Nouvelle Librairie Nationale, 1924 .

--- Bergsonian Philosophy and Thomism. Trans. Mabelle L. Andison and J. Gordon Andison. New York: Philosophi cal Library, 1955.

Nye, Mary Jo. "The Boutroux Circle And Poincare's Conventionalism." Journal of the History of Ideas XL-1 January-March 1979: 107-120.

O'Connell, Robert J., S.J. William James on The Courage to Believe. New York: Fordham University Press, 1984.

Pascal, Blaise. Penseés. 1966. Trans. A.J. Krailsheimer. New York: Penguin Books, Ltd., 1981.

Paul, Harry W. "The Debate Over the Bankruptcy of Science in 1895." French Historical Studies V Spring 1968: $299-327$.

-... "In Quest of Kerygma: Cathlic Intellectual Life In Nineteenth-Century France." American Historical

Review LXXV.2 (1969): 387-423. 
---. "The Crucifix and the Crucible: Catholic Scientists in the Third Republic." The Catholic Historical

Review LVIII Apr. 1972: $195-219$.

---. "The Issue of Decline in Nineteenth-Century French Science." French Historical Studies VII.3-Spring 1972: $416-450$.

--- The Edge of Contingency--French Catholic Reaction to Scientific Change from Darwin to Duhem. Gainesville: University Presses of Florida, 1979.

Perry, Ralph Barton. The Thought and Character of William James. 2 vols. Boston: Little, Brown and Company, 1935.

-.- Present Philosophical Tendencies. New York: George Braziller, Inc., 1955.

Prat, Louis. "Les Derniers Entretiens de Charles Renouvier." Revue de Métaphysique et de Morale XII (1904): $149-185$.

Reardon, Bernard. Liberalism and Tradition: Aspects of Catholic Thought in Nineteenth-Century France. New York: Cambridge University Press, 1975.

Reardon, Michael F. "Science and Religious Modernism: The New Apologetic in France, 1890-1913." The Journal of Religion 57.1 Jan. 1977: 48-63.

Rothwell, Fred. "Emile Boutroux." The Monist vol. XXXII No. 2-Apr. 1922: 161-163.

Ruggiero, Guido De. Modern Philosophy. Trans. A. Howard Hannay and R.G. Collingwood. New York: The MacMilian Company, 1921.

-- . The History of European Liberalism. 1927. Trans. R.G. Collingwood. Boston: Beacon Paperback, 1959.

Said, Edward w. Orientalism. New York: Vintage Books, 1979 .

Scott, Frederick J.D. "William James and Maurice Blondel." The New Scholasticism XXXI I 1972:32-44.

--. William James: Selected Unpubl ished Correspondence 1885-1910. Columbus: Ohio state University Press, 1986 . 
Simon, W.M. "Comte's Orthodox Disciples: The Rise and Fall of A Cenacle." French Historical studies IV.1 Spring, 1965: 42-62.

Soltau, Roger Henry. French Political Thought in the 19th Century. New York: Russell \& Russell, 1959.

Somerville, James M. "Maurice Blondel 1861-1949." Thought XXXVI.142 Autumn 1961: 371-410.

Stebbing, L. Susan. Pragmatism and French Voluntarism. Cambridge: Cambridge University Press, 1914.

stock, Phyllis H. "Students versus the University in PreWorld War Paris." French Historical studies VII.I Spring 1971: 93-110.

Sutton, Michael. Nationalism, Positivism and Catholicism: The Politics of Charles Maurras and French Catholics 1890-1914. London: Cambridge University Press, 1982 .

Valensin, Auguste. Maurice Blondel. Paris: Librairie Lecoffre, 1934.

Wahl, Jean Andre. The Pluralist Philosophies of Enqland $\&$ America. Trans. Fred Rothwell. London: The Open Court Company, 1925.

Wright, Charles H.C. A History of the Third French Republic. 1916. New York: Books Eor Libraries Press, 1970. 